University of Nebraska - Lincoln

DigitalCommons@University of Nebraska - Lincoln

\title{
Ecological effects of lead mining on Ozark streams: In-situ toxicity to woodland crayfish (Orconectes hylas)
}

\author{
Ann L. Allert \\ United States Geological Survey, aallert@usgs.gov \\ James F. Fairchild \\ United States Geological Survey, jfairchild@usgs.gov \\ Robert J. DiStefano \\ Central Regional Office and Conservation Research Center \\ C.J. Schmitt \\ United States Geological Survey, cjschmitt@usgs.gov \\ William G. Brumbaugh \\ United States Geological Survey, bbrumbaugh@usgs.gov \\ See next page for additional authors
}

Follow this and additional works at: https://digitalcommons.unl.edu/usgsstaffpub

Allert, Ann L.; Fairchild, James F.; DiStefano, Robert J.; Schmitt, C.J.; Brumbaugh, William G.; and Besser, J.M., "Ecological effects of lead mining on Ozark streams: In-situ toxicity to woodland crayfish (Orconectes hylas)" (2009). USGS Staff -- Published Research. 531.

https://digitalcommons.unl.edu/usgsstaffpub/531

This Article is brought to you for free and open access by the US Geological Survey at DigitalCommons@University of Nebraska - Lincoln. It has been accepted for inclusion in USGS Staff -- Published Research by an authorized administrator of DigitalCommons@University of Nebraska - Lincoln. 


\section{Authors}

Ann L. Allert, James F. Fairchild, Robert J. DiStefano, C.J. Schmitt, William G. Brumbaugh, and J.M. Besser 


\title{
Ecological effects of lead mining on Ozark streams: In-situ toxicity to woodland crayfish (Orconectes hylas)
}

\author{
A.L. Allert ${ }^{\text {a,* }}$, J.F. Fairchild ${ }^{a}$, R.J. DiStefano ${ }^{b}$, C.J. Schmitt ${ }^{a}$, W.G. Brumbaugh ${ }^{\text {a }}$, J.M. Besser ${ }^{\text {a }}$ \\ ${ }^{a}$ US Geological Survey, Columbia Environmental Research Center (USGS/CERC), 4200 New Haven Road, Columbia, MO 65201, USA \\ ${ }^{\mathrm{b}}$ Missouri Department of Conservation, 1110 South College Avenue, Columbia, MO 65201, USA
}

\section{A R T I C L E I N F O}

\section{Article history:}

Received 22 April 2008

Received in revised form

28 July 2008

Accepted 28 August 2008

Available online 20 December 2008

\section{Keywords:}

Crayfish

Orconectes hylas

Lead-zinc mining

Lead

Zinc

Cadmium

Nickel

Cobalt

In-situ toxicity

\begin{abstract}
A B S T R A C T
The Viburnum Trend mining district in southeast Missouri, USA is one of the largest producers of lead-zinc ore in the world. Previous stream surveys found evidence of increased metal exposure and reduced population densities of crayfish immediately downstream of mining sites. We conducted an insitu 28-d exposure to assess toxicity of mining-derived metals to the woodland crayfish (Orconectes hylas). Crayfish survival and biomass were significantly lower at mining sites than at reference and downstream sites. Metal concentrations in water, detritus, macroinvertebrates, fish, and crayfish were significantly higher at mining sites, and were negatively correlated with caged crayfish survival. These results support previous field and laboratory studies that showed mining-derived metals negatively affect $O$. hylas populations in streams draining the Viburnum Trend, and that in-situ toxicity testing was a valuable tool for assessing the impacts of mining on crayfish populations.
\end{abstract}

Published by Elsevier Inc.

\section{Introduction}

Extensive deposits of lead $(\mathrm{Pb})$ ore have been mined in Missouri for more than three centuries. Mining of the Viburnum Trend in southeast Missouri, USA, which contains economically significant $\mathrm{Pb}-\mathrm{zinc}(\mathrm{Zn})$ ores, began in the 1950s. By 1970, the Viburnum Trend was the largest $\mathrm{Pb}$-producing region in the world (Ryck and Whitley, 1974). Deposits within the Viburnum Trend also contain considerable quantities of copper(Cu), cobalt- (Co), and nickel- (Ni) bearing minerals (Jessey, 1981). Although the mining district remains a major producer of $\mathrm{Pb}$, and a minor producer of $\mathrm{Zn}$ and $\mathrm{Cu}$ (Missouri Department of Natural Resources, 2004), there is no commercial recovery of Co or Ni (Kuck, 2004; Shedd, 2004). We conducted no analyses of copper because previous studies have indicated that it is a minor component of metal contamination from mining in the Viburnum Trend (Besser et al., 2008; Brumbaugh et al., 2007).

Although modern mining practices incorporate efficient extraction technologies and operate within environmental regulations, early studies (Duchrow, 1983; Ryck and Whitley, 1974;

\footnotetext{
* Corresponding author. Fax: +1573 8761896.

E-mail address: aallert@usgs.gov (A.L. Allert).
}

Wixson, 1977) showed that metal exposures to aquatic biota had occurred within the Viburnum Trend. Subsequent investigations have documented elevated metal concentrations in water, stream sediments, and aquatic food chains (Besser et al., 2006; Brumbaugh et al., 2007; Schmitt et al., 2007a,b), and the loss of biota including crayfish (Allert et al., 2008) and other macroinvertebrates (unpublished data; B. Poulton, USGS, Columbia, MO). In addition, sportfish including smallmouth bass (Micropterus dolomieu), longear sunfish (Lepomis megalotis), and suckers (Catostomidae) are known to contain $\mathrm{Pb}$ at concentrations exceeding recommended human food consumption levels (Missouri Department of Health and Senior Services, 2005).

Crayfish hold an intermediate trophic position and facilitate the flow of nutrients and energy in aquatic ecosystems (Lodge et al., 1995). Crayfish process a significant portion of organic matter in streams (Usio, 2000), breaking allocthonous and autochthonous material into smaller particles that are ultimately consumed by aquatic insects, snails, and microbial fauna (Huryn and Wallace, 1987; Parkyn et al., 2001). Crayfish are the dominant invertebrate biomass in some Ozark streams (Rabeni et al., 1995) and are the primary food source for several centrarchid fishes (Whitledge and Rabeni, 1997). Crayfish are also prey for more than 200 species of insects, arachnids, amphibians, fish, reptiles, birds, and mammals in and around North American water bodies (DiStefano, 2005). 
The southern-most mines within the Viburnum Trend are located in the headwaters of the Black River watershed (Fig. 1). The woodland crayfish (Orconectes hylas) is endemic to the Black River watershed (Pflieger, 1996) and occurs at high densities $\left(25-37 / \mathrm{m}^{2}\right)$ in riffle habitats of Ozark streams (DiStefano et al., 2002). Allert et al. (2008) reported reduced densities of 0 . hylas $\left(0-2 / \mathrm{m}^{2}\right)$ at sites immediately downstream of mining activities compared with densities $\left(15-20 / \mathrm{m}^{2}\right)$ at sites upstream of mining or at sites greater than $10 \mathrm{~km}$ downstream of mining areas in the Black River watershed. These findings suggest that mining activities are adversely affecting crayfish populations. We therefore conducted chronic in-situ exposures of $O$. hylas in two tributaries of the Black River watershed with the following objectives: (1) to evaluate crayfish responses relative to metal exposure through aqueous and dietary pathways, and (2) to evaluate the effects of mining-derived metals on survival and growth of 0 . hylas.

\section{Methods \\ 2.1. Study area}

Crayfish cages were deployed from 30 June to 28 July 2005 at seven sites in three tributaries of the Black River (Table 1). Previously collected physical, chemical and biological data (Allert et al., 2008; Besser et al., 2006; Brumbaugh et al., 2007) were used to identify reference sites (sites upstream of known mining activities); mining sites ( sites impacted by mining activity); and downstream sites, where possible biological recovery may occur. Two sites were designated as

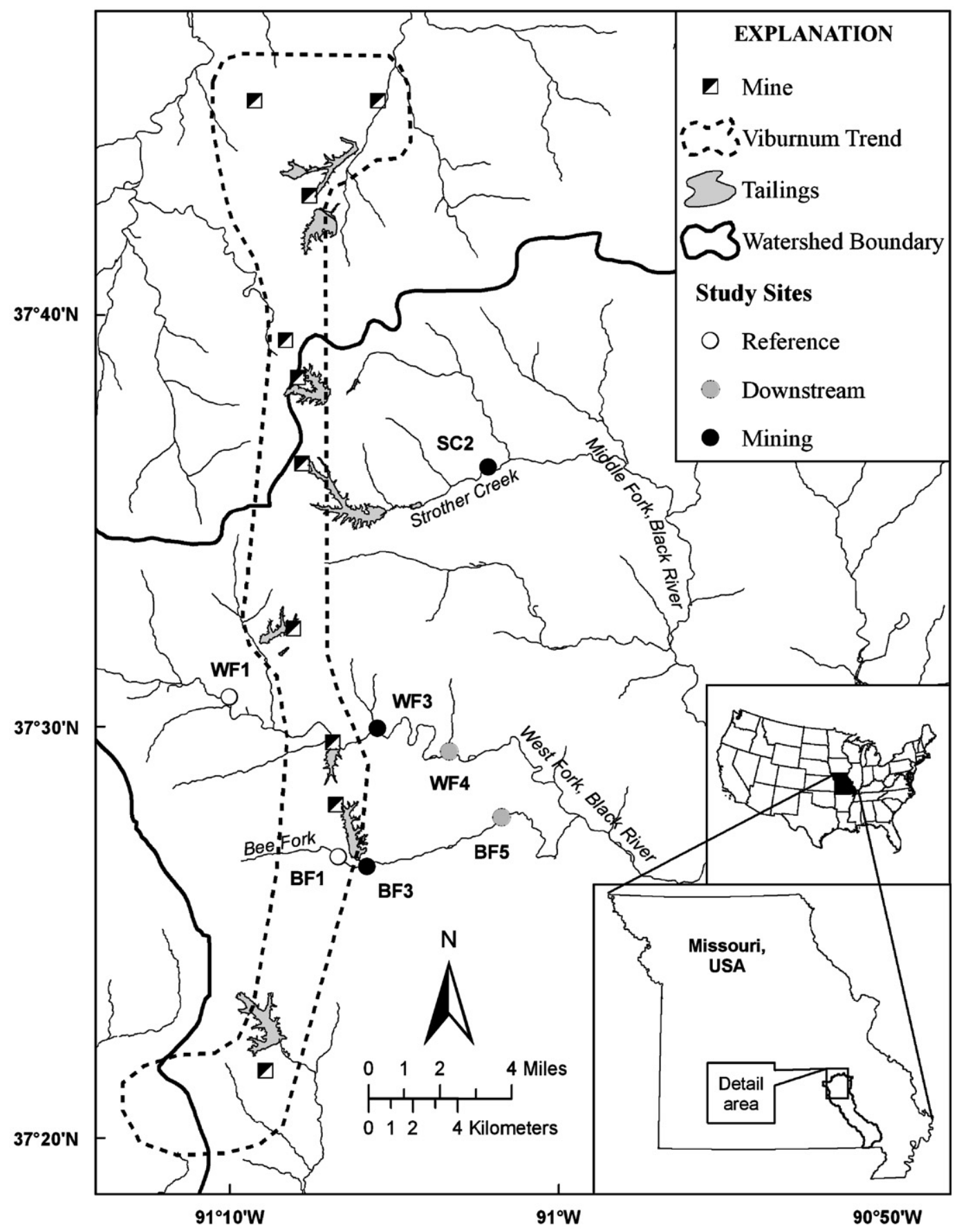

Fig. 1. Map of study sites in the Black River watershed of Missouri, USA. 
Table 1

Sampling sites and cage locations in three tributaries of the Black River.

\begin{tabular}{|c|c|c|c|c|c|c|}
\hline Site & Stream & Latitude, longitude $^{a}$ & Prominent mining feature upstream & $\begin{array}{l}\text { Stream } \\
\text { order }\end{array}$ & $\begin{array}{l}\text { Stream distance } \\
\text { from tailings or } \\
\text { mine }(\mathrm{km})\end{array}$ & $\begin{array}{l}\text { Type of } \\
\text { site }\end{array}$ \\
\hline $\mathrm{SC} 2$ & Strother Creek & $37^{\circ} 36^{\prime} 07.2^{\prime \prime}, 91^{\circ} 01^{\prime} 40.8^{\prime \prime}$ & Effluent pond; Buick tailings & 2 & 3.7 & M \\
\hline WF1 & West Fork & $37^{\circ} 30^{\prime} 39.6^{\prime \prime}, 9^{\circ} 09^{\prime} 43.2^{\prime \prime}$ & None & 2 & NA & $\mathrm{R}$ \\
\hline WF3 & West Fork & $37^{\circ} 29^{\prime} 49.2^{\prime \prime}, 9^{\circ} 05^{\prime} 13.2^{\prime \prime}$ & Brushy Creek tailings; West Fork tailings & 2 & 2.2 & M \\
\hline WF4 & West Fork & $37^{\circ} 29^{\prime} 13.2^{\prime \prime}, 91^{\circ} 03^{\prime} 03.6^{\prime \prime}$ & Brushy Creek tailings; West Fork tailings & 2 & 10.1 & $\mathrm{D}$ \\
\hline BF1 & Bee Fork & $37^{\circ} 26^{\prime} 43.4^{\prime \prime}, 9^{\circ} 06^{\prime} 29.4^{\prime \prime}$ & None & 1 & NA & $\mathrm{R}$ \\
\hline BF3 & Bee Fork & $37^{\circ} 26^{\prime} 28.7^{\prime \prime}, 91^{\circ} 05^{\prime} 38.0^{\prime \prime}$ & Fletcher clarification dam and tailings & 1 & 0.4 & M \\
\hline BF5 & Bee Fork & $37^{\circ} 27^{\prime} 36.0^{\prime \prime}, 91^{\circ} 01^{\prime} 30.0^{\prime \prime}$ & Fletcher clarification dam and tailings & 2 & 7.4 & $\mathrm{D}$ \\
\hline
\end{tabular}

Latitude, longitude as determined by global positioning system (GPS) receiver. $\mathrm{R}=$ reference site; $\mathrm{M}=\mathrm{mining}$ site; $\mathrm{D}=\mathrm{downstream}$ site; $\mathrm{NA}=$ not applicable.

a (GPS; $\pm 10 \mathrm{~m}$ ) based on the WGS84 geodetic datum.

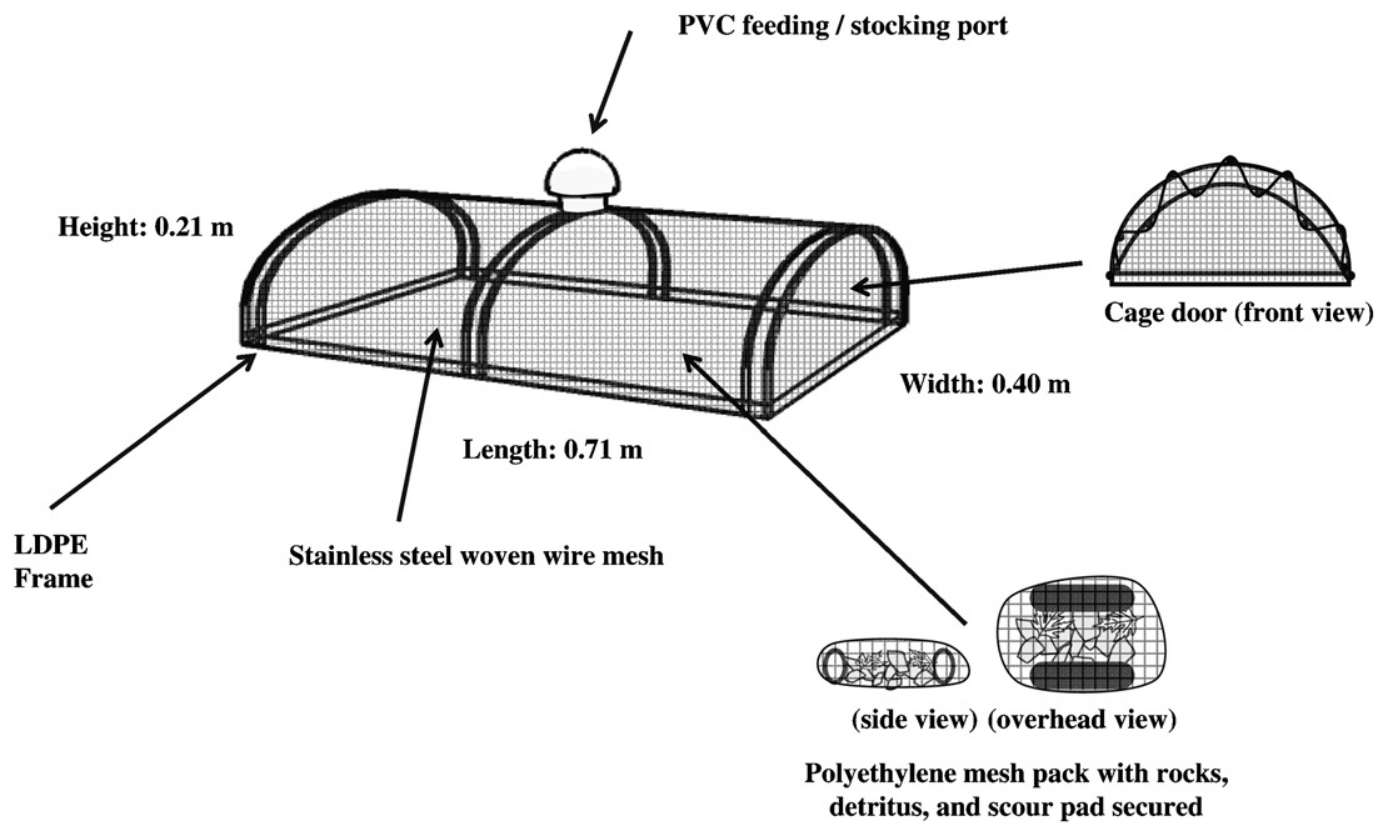

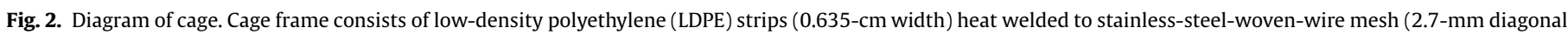

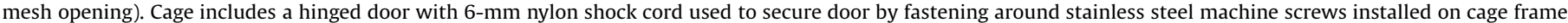

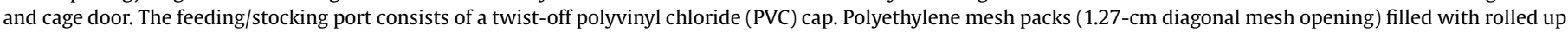

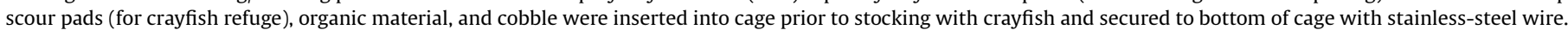

reference sites (WF1, BF1); three as mining sites ( $\mathrm{SC} 2, \mathrm{WF} 3, \mathrm{BF} 3$ ); and two as downstream sites (WF4, BF5). Sites classified as mining sites were $0.4-3.7 \mathrm{~km}$ downstream of mining activity, whereas those classified as downstream sites were at least $7 \mathrm{~km}$ downstream of mining-related activity.

\subsection{Crayfish collection and rearing}

Ovigerous 0 . hylas females were collected from the reference site on the West Fork (WF1) in early April in 2005 and returned to the US Geological Survey's Columbia Environmental Research Center (CERC) located in Columbia, MO, USA. Sixteen females were held in individual 2-L flow-through aquaria with CERC well water (temperature $18^{\circ} \mathrm{C}, \mathrm{pH} 7.7$, alkalinity $254 \mathrm{mg} / \mathrm{L}$ as $\mathrm{CaCO}_{3}$, hardness $286 \mathrm{mg} / \mathrm{L}$ as $\mathrm{CaCO}_{3}$ ) and fed frozen brine shrimp (San Francisco Bay Brand, Inc., San Francisco, CA, USA) ad libitum daily. Upon hatching and detaching from the adult females, juvenile crayfish were placed in a fiberglass tank filled with CERC well water and fed flake food (Ziegler Brothers, Inc., Gardner, PA, USA) ad libitum daily until their body width was greater than $2 \mathrm{~mm}$. Prior to stocking crayfish into cages, a subset of crayfish available for stocking into cages $(n=88)$ was measured for mean carapace length ( $C L$, from tip of rostrum to posterior edge of the cephalothorax, to the nearest $0.1 \mathrm{~mm}$ ) and weighed (to the nearest $0.01 \mathrm{~g}$ ).

\subsection{Toxicity test}

A 28-d in-situ toxicity test was conducted with juvenile $O$. hylas, at seven sites in the West Fork, Bee Fork, and Strother Creek of the Black River watershed (Fig. 1). Crayfish were exposed in hemicylindrical $\left(0.28-\mathrm{m}^{2}\right)$ cages constructed of stainlesssteel wire mesh (2.7-mm diagonal opening) and polyethylene (LDPE) reinforcing strips (Fig. 2). We collected cobble substrates $(2.5-7.5 \mathrm{~cm}$ ) and approximately $10-\mathrm{g}$ organic material (henceforth detritus) from each site to provide both food and shelter for caged crayfish. Cobble, detritus, and three polyethylene scour pads were placed in three polyethylene-mesh packs $(15-\mathrm{cm}$ length $\times 30-\mathrm{cm}$ width; $1.27-\mathrm{cm}$ diagonal opening), which were closed using plastic cable ties and secured to the bottom of each cage using stainless-steel wire. Prior to placing organic material into the mesh packs, all predatory insects (i.e., Odonata and Plecoptera larvae) were removed. The bottom of the cages were buried $2-4-\mathrm{cm}$ into the stream sediment to expose crayfish to sub-surface water and to anchor the cages. Minced fish (largescale stonerollers, Campostoma oligolepis; henceforth stonerollers) from each site were added to each cage weekly in increasing increments to maintain dietary rations proportional to anticipated crayfish biomass $(0.1,0.1,0.2,0.4 \mathrm{~g}$ minced fish in weeks $1,2,3$, and 4 , respectively). Ten juvenile crayfish were placed in each of the six cages at each site except at SC2, where seven cages were deployed. Three cages ( $n=30$ crayfish) were sampled on both day 14 and 28 , 
except at SC2, where four cages were sampled on day 28. Crayfish were measured (CL and wet weight) and frozen for metal analyses. Test endpoints included survival and growth. Biomass (i.e., standing crop) at day 28 was estimated by multiplying the number of survivors by the mean wet weight of survivors at each site.

\subsection{Wild crayfish collections}

Wild crayfish ( 0 . hylas) were collected on days 0 and 28 of the toxicity test at each site to compare CL, wet weight, and metal concentrations of wild crayfish to those stocked in cages. Crayfish were collected by disturbing substrate directly upstream of a small kick seine (1-m length $\times 1.5$-m height) with 3-mm delta mesh (Flinders and Magoulick, 2005). Wild crayfish were collected within $200 \mathrm{~m}$ of cage placement. Collections were made upstream or downstream of cage placement, depending on the nearest available riffle, and number of kick seines required to collect 30 individuals. All crayfish collected were identified to species, measured (CL and wet weight) and frozen for metal analyses.

\subsection{Water samples}

Surface water quality parameters (temperature, $\mathrm{pH}$, conductivity, dissolved oxygen, and turbidity) were measured in-situ on days $0,7,14,21$, and 28 using a Hydrolab $^{\mathbb{B}}$ Quanta meter (Loveland, CO, USA). A sub-surface grab sample was collected in a pre-cleaned 4-L carboy at each site on days 0,14 , and 28 for additional water quality and nutrient analyses at CERC. Alkalinity and hardness were measured by titration (APHA, 2005). Sulfate was measured by colorimetric detection with a Hach ${ }^{\mathbb{R}} 2100$ spectrophotometer (Loveland, CO, USA). Recovery of reference standards used as laboratory control samples for surface water quality parameters $(\mathrm{pH}$, conductivity, dissolved oxygen, turbidity, alkalinity, hardness, and sulfate) ranged from $90 \%$ to $118 \%$. Overall, detection and recoveries of water quality parameters were within acceptable criteria, thus none of the sample results were corrected.

Samples for dissolved nutrient analyses were filtered through $0.4-\mu \mathrm{m}$ polycarbonate filters under vacuum pressure within 4 days of collection. Nutrients were measured in surface water samples with a Technicon ${ }^{\mathbb{R}}$ Autoanalyzer (Tarrytown, NY, USA) using colorimetric detection (APHA, 2005). Total ammonia $\left(\mathrm{NH}_{3}\right)$ was analyzed using a salicylate/nitroprusside colorimetric reaction. Dissolved nitrite/nitrate $\left(\mathrm{NO}_{2} / \mathrm{NO}_{3}\right)$ was measured following cadmium reduction and measured using colorimetric reaction (APHA, 2005). Soluble reactive phosphorus (SRP) was determined using the automated ascorbic acid method (APHA, 2005). Samples for total phosphorous (TP) and total nitrogen (TN) were digested in sodium hydroxide and potassium persulfate then analyzed using the automated ascorbic acid and the automated cadmium reduction methods, respectively (APHA, 2005). Dissolved organic carbon (DOC) was analyzed using a persulfate/UV digestion followed by colorimetric analysis of $\mathrm{CO}_{2}$. Method limits of detection limits (MLDs) for nutrients are listed in Table S-1. Recovery of reference standards used as laboratory control samples for nutrients ranged from $100 \%$ to $128 \%$, except for one standard for $\mathrm{NH}_{3}(1 \mathrm{mg} \mathrm{N} / \mathrm{L})$ that was $145 \%$. Overall, detection and recoveries of nutrients were within acceptable criteria and all measured concentrations exceeded MLDs, thus none of the sample results were corrected for recovery.

\subsection{Metal concentrations}

Water samples were filtered for metal analyses using a polypropylene syringe and filter cartridge $(0.45-\mu \mathrm{m}$ pore size) into a pre-cleaned polyethylene bottle on-site, and placed on ice. Water samples were subsequently acidified to $1 \%(\mathrm{v} / \mathrm{v})$ with nitric acid (J.T. Baker Inc., Phillipsburg, NJ, USA) within 4 days of collection.

Surface water samples were analyzed for $\mathrm{Pb}, \mathrm{Zn}, \mathrm{Cd}, \mathrm{Ni}$, and Co by inductivelycoupled plasma-mass spectrometry (ICP-MS) (Brumbaugh et al., 2007; May et al., 1997). Calibration verification, method limits of detection, and recoveries of metals in reference solutions, duplicates, and spikes were all within acceptable criteria and all measured concentrations exceeded MLDs (Brumbaugh et al., 2007).

Detritus, macroinvertebrates (i.e., Ephemeroptera, Odonata, Plecoptera, Megaloptera, Trichoptera, Diptera, and Chirononmidae), stonerollers, and whole crayfish from each site were analyzed for $\mathrm{Pb}, \mathrm{Zn}, \mathrm{Cd}$, Ni, and Co by ICP-MS (Besser et al., 2006; Brumbaugh et al., 2005). Tissues were lyophilized and reduced to a coarse powder by mechanical crushing in a glass vial with a glass rod. Neither exoskeletons nor gut contents of any of the biota were removed before analysis. A dry mass of $0.25 \mathrm{~g}$ from each composited sample was digested using concentrated nitric acid and microwave heating. Quality control measures incorporated at the digestion stage included digestion blanks, certified reference materials, replicates, and spikes. A calibration blank and an independent calibration verification standard were analyzed with every 10 samples to confirm the calibration status of the ICP-MS during instrumental analyses of digestates. The MLDs for detritus, macroinvertebrates, stonerollers, and crayfish are listed in Table S-2. All measured concentrations exceeded the MLDs.

Recoveries of the elements from reference materials (fish, mussel, oyster, plant, and plankton) ranged from $87 \%$ to $115 \%$. Relative percent differences (RPDs) for replicate analyses were $<26 \%$ for all elements except for $\mathrm{Pb}$ analyses of one sample of detritus (50\%) and one sample of macroinvertebrates (85\%). Instrumental precision, estimated by determining the RPDs from the duplicate analysis of detritus and biota digestates, was $<4 \%$. Recoveries of method spikes for all five metals in 14 separate spiked samples of all the sample types analyzed averaged $97 \%$. Post-digestion or analysis spike recoveries ranged from $83 \%$ to $104 \%$. As a check for potential interferences, dilution percent differences (DPDs) based on $5 \mathrm{X}$ dilutions of detritus and biota sample digestates were determined; DPDs were $<10 \%$ for all metals. Blank-equivalent concentrations (BECs) for digestion blanks were less than corresponding MLDs; therefore sample results were not corrected for BECs. Overall, quality assurance results indicated that the methods used provided acceptable accuracy and precision, thus none of the sample results were corrected.

\subsection{Statistical analysis}

Statistical analyses were conducted using Statistical Analysis System (SAS) for Windows (Release 9.1; SAS Institute, Cary, NC, USA). Censored values ( $<$ MLD) were replaced with $50 \%$ of the MLD for statistical computations and graphing. Survival and biomass data of caged crayfish on day 28 of the toxicity test and the overall means (e.g., data from days $0,7,14,21$, and 28 ) for water quality, nutrients, and metal concentrations were used in the statistical analyses. No wild crayfish were collected within $200 \mathrm{~m}$ of our cages at SC2, so our search was expanded until one adult wild crayfish was collected at a distance greater than $500 \mathrm{~m}$ away from the cages; therefore it was not used in the statistical analyses of CL and wet weight of wild crayfish. However, data from this individual is present in tables and figures for comparative purposes. All data were tested for normality and homogeneity of variance using the PROC UNIVARIATE module in SAS. Data were not normally distributed, therefore rank transformation were used in statistical analyses. Differences in caged crayfish survival and biomass among sites and groups of sites were tested using nested analysis-of-variance (ANOVA; cages nested within site), with site considered a fixed effect. Differences in caged crayfish survival among groups of sites were tested as planned non-orthogonal contrasts using single degree-of-freedom $F$-tests. The mean square for cage survival within site was used in all tests, which were conducted using the PROC GLM module in SAS Differences in crayfish survival and biomass among individual sites were also evaluated with Duncan's multiple range test. Differences in wild crayfish growth, water quality, nutrient, and metal concentrations among groups of sites were also tested using the same procedures. Differences in mortality, size of crayfish, water quality, nutrient, and metal concentrations were tested on a stream-by-stream basis using the Kruskal-Wallis test. Results were similar to those that included all seven sites; therefore we list only exceptional results in Table S-3. Finally associations among caged crayfish survival and biomass on day 28 , wild crayfish (excluding SC2) CL and wet weight, water quality, nutrient, and metal concentrations were examined with Spearman's correlation analysis. A significance level of $P<0.05$ was used to judge all statistical tests.

\section{Results}

\subsection{Toxicity test}

Mean percent survival of caged crayfish on day 28 (henceforth survival) was significantly greater at reference sites (90\%) than at mining sites (39\%; Table 2; Fig. 3), and decreased sharply with increasing metal concentrations in surface water (Fig. 4). When analyzed on a stream-by-stream basis, survival at the mining site (BF3) in the Bee Fork was significantly lower; however, survival was not significantly lower at the mining site (WF3) in the West Fork (Table S-3).

Mean CL and wet weight of caged crayfish at all sites on day 28 were significantly greater than those on day $0 \quad(n=88$; $\mathrm{CL}=6.7 \pm 0.11$; wet wt. $=0.06 \pm 0.003)$, except mean wet weight of crayfish at SC2 (Table 2). Mean CL and wet weight of crayfish at day 28 were significantly greater at downstream sites than at reference or mining sites; however, CL and weight were not significantly different among mining and reference sites (Table 2). Mean biomass of crayfish at reference and downstream sites on day 28 was significantly greater than at mining sites (Table 2; Fig. 3). 
Table 2

Number (n) of living crayfish, percent (\%) survival, carapace length (CL), and wet weight (means with standard error in parenthesis) of caged Orconectes hylas.

\begin{tabular}{|c|c|c|c|c|c|}
\hline Day/site & $n$ & \% Survival & $\mathrm{CL}(\mathrm{mm})$ & Wet wt. (g) & Biomass $\left(\mathrm{g} / \mathrm{m}^{2}\right)$ \\
\hline \multicolumn{6}{|l|}{ Day 14} \\
\hline \multicolumn{6}{|l|}{ Reference sites } \\
\hline $\mathrm{WF}^{\mathrm{a}}$ & 24 & $83(3) b$ & $9.3(0.19) \mathrm{b}$ & $0.17(0.01) c$ & $4.3(0.7) \mathrm{ab}$ \\
\hline BF1 & 28 & $93(7) a$ & $8.5(0.22) c$ & $0.13(0.01) \mathrm{d}$ & $5.3(0.8) a b$ \\
\hline Group mean & & 88 (4) A & $8.9(0.16) \mathrm{C}$ & $0.15(0.01) \mathrm{B}$ & $4.7(0.5) \mathrm{A}$ \\
\hline \multicolumn{6}{|l|}{ Mining sites } \\
\hline $\mathrm{SC} 2$ & 23 & $84(9) b$ & $8.4(0.24) c$ & $0.12(0.01) \mathrm{d}$ & $3.3(0.4) b$ \\
\hline $\mathrm{WF}^{\mathrm{b}}$ & 27 & $90(6) \mathrm{a}$ & $9.7(0.21) b$ & $0.20(0.01) b c$ & $5.3(0.6) \mathrm{ab}$ \\
\hline BF3 & 17 & $57(23) \mathrm{b}$ & $9.8(0.31) b$ & $0.18(0.02) \mathrm{c}$ & $4.0(1.8) a b$ \\
\hline Group mean & & 77 (27) A & $9.3(0.16) \mathrm{A}$ & $0.17(0.01) \mathrm{B}$ & $4.3(0.6) \mathrm{B}$ \\
\hline \multicolumn{6}{|c|}{ Downstream sites } \\
\hline WF4 & 28 & $84(3) b$ & $11.2(0.17) \mathrm{a}$ & $0.32(0.02) \mathrm{a}$ & $8.3(1.8)$ a \\
\hline BF5 & 29 & $97(3) \mathrm{a}$ & $9.8(0.23) \mathrm{b}$ & $0.23(0.02) b$ & $6.0(1.8) a b$ \\
\hline Group mean & & $92(8) \mathrm{A}$ & 10.5 (0.01) B & $0.27(0.01) \mathrm{A}$ & $7.3(1.3) \mathrm{A}$ \\
\hline \multicolumn{6}{|l|}{ Day 28} \\
\hline \multicolumn{6}{|l|}{ Reference sites } \\
\hline WF1 & 27 & $90(6) \mathrm{a}$ & $10.5(0.33) b c$ & $0.40(0.02) \mathrm{cd}$ & $1.2(3.3) \mathrm{c}$ \\
\hline BF1 & 26 & $90(0) \mathrm{a}$ & $10.8(0.37) \mathrm{b}$ & $0.29(0.03) \mathrm{de}$ & 14.7 (2.3) bc \\
\hline Group mean & & 90 (3) A & $10.7(0.15) \mathrm{B}$ & $0.33(0.14) \mathrm{B}$ & 13.3 (1.9) B \\
\hline \multicolumn{6}{|l|}{ Mining sites } \\
\hline $\mathrm{SC} 2^{\mathrm{c}}$ & 3 & 7 (3) d & $9.2(0.03) c$ & $0.17(0.03) \mathrm{e}$ & $0.3(0.2) \mathrm{d}$ \\
\hline WF3 & 20 & 67 (9) bc & $11.3(0.47) \mathrm{b}$ & $0.37(0.05) \mathrm{cd}$ & $7.7(2.5) \mathrm{cd}$ \\
\hline BF3 & 16 & $53(3) c$ & $13.2(0.46) \mathrm{a}$ & $0.58(0.05) a b$ & $7.7(3.5) \mathrm{cd}$ \\
\hline Group mean & & 39 (9) B & 11.9 (0.36) B & $0.44(0.04) \mathrm{B}$ & $4.7(1.6) \mathrm{C}$ \\
\hline \multicolumn{6}{|c|}{ Downstream sites } \\
\hline WF4 & 26 & $87(3) a b$ & $14.0(0.31) \mathrm{a}$ & $0.71(0.05) a$ & 32.0 (4.9) a \\
\hline BF5 & 25 & 77 (13) ab & $12.9(0.3) \mathrm{a}$ & $0.53(0.04) b c$ & $22.7(5.2) \mathrm{ab}$ \\
\hline Group mean & & $82(16) \mathrm{A}$ & 13.4 (1.6) A & $0.61(0.03) \mathrm{A}$ & $27.3(3.8) \mathrm{A}$ \\
\hline
\end{tabular}

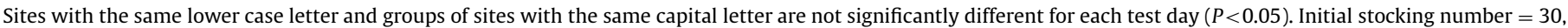
unless otherwise noted.

a Stocking number $=29$

b Stocking number $=31$.

c Stocking number $=40$.

\subsection{Wild crayfish collections}

Very few wild crayfish were collected at any of the mining sites on either day 0 or 28 , despite significant sampling effort (i.e., $>15$ kick seines). Mean wet weight of wild crayfish on days 0 and 28 were significantly greater at reference and downstream sites than mining sites; however, there was no significant difference in CL among groups of sites on day 28 (Table 3 ).

\subsection{Water quality}

Mean conductivity, hardness, and sulfate concentrations in surface water were significantly higher at mining and downstream sites than reference sites (Table 4); whereas alkalinity was significantly lower at downstream sites than at reference and mining sites (Table 4). Reference sites had significantly higher turbidity (Table 4); however, values were still very low. Dissolved oxygen and $\mathrm{pH}$ at reference sites were significantly lower than mining and downstream sites (Table 4); however, at all the sites, the range in dissolved oxygen and $\mathrm{pH}$ readings were narrow.

Ammonia, $\mathrm{NO}_{2} / \mathrm{NO}_{3}$, and $\mathrm{TN}$ concentrations in surface water from mining sites were significantly higher than reference and downstream sites (Table 5). Soluble reactive phosphorous concentrations in surface waters from mining and downstream sites were significantly lower than reference sites (Table 5); however, there were no significant differences in TP concentrations among reference, mining and downstream sites (Table 5). Dissolved organic carbon was significantly lower at downstream sites than reference or mining sites (Table 5).

Analyses on a stream-by-stream basis produced slightly different results for several parameters. There were no significant differences in dissolved oxygen or DOC at sites in the West Fork; however, there were at sites in the Bee Fork (Table S-3). There were significant differences in alkalinity at sites in the West Fork; however, alkalinity was not significantly different at sites in the Bee Fork. There was no significant difference in SRP or $\mathrm{NH}_{3}$ in either the Bee Fork or West Fork, despite an overall significant difference when SC2 was included in the analyses.

\subsection{Metal concentrations}

Concentrations of metals in surface water were all below surface water chronic criteria (WQC; USEPA, 2002; Table 6). Cobalt concentrations in surface water were also all below a proposed Canadian guideline for chronic exposure of $4 \mu \mathrm{g} \mathrm{Co} / \mathrm{L}$ (Nagpal, 2004). However, concentrations of $\mathrm{Pb}, \mathrm{Zn}, \mathrm{Ni}$, and $\mathrm{Co}$ in surface waters were significantly higher at mining sites compared with reference or downstream sites (Table 6).

Concentrations of all metals in detritus, macroinvertebrates, stonerollers, and caged crayfish were significantly higher at 
a

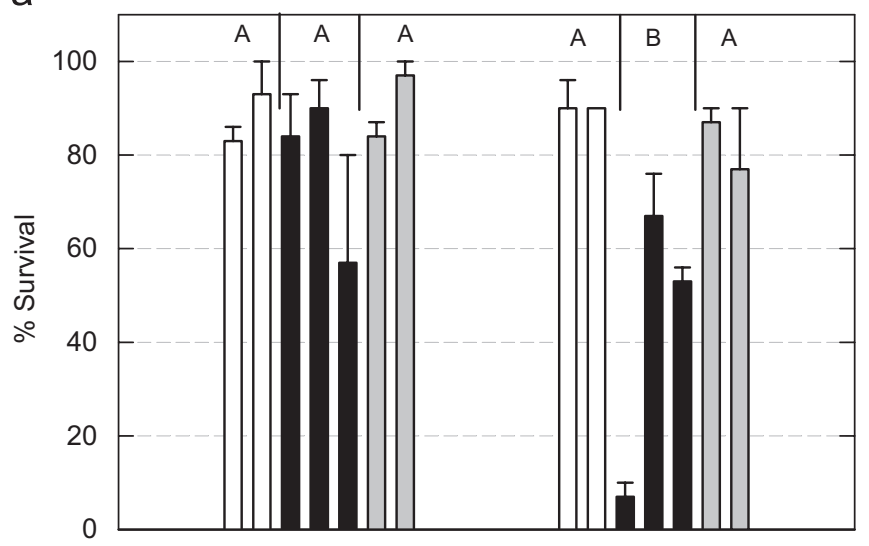

b

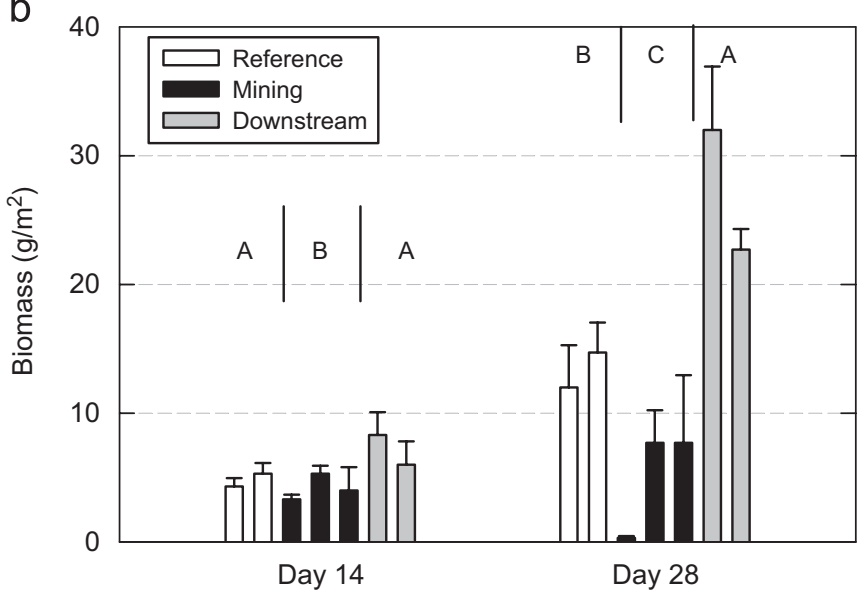

Fig. 3. (a) Mean percent (\%) survival and (b) mean biomass of caged Orconectes hylas within groups of sites on days 14 and 28 . Groups of sites with the same letter are not significantly different $(P<0.05)$.

mining sites than at reference or downstream sites, with the exception of $\mathrm{Cd}$ concentrations in macroinvertebrates, and stonerollers (Table 7; Fig. 5). Mean concentration of $\mathrm{Pb}$ in wild crayfish was significantly higher at mining sites than at reference or downstream sites (Table 7). Mean concentrations of $\mathrm{Zn}$ and Co in all sample types were highest at SC2. Lead and Ni concentrations were highest at SC2 and/or BF3. Metal concentrations in samples at all mining sites were generally two to ten-fold higher in all sample types compared with those at downstream or reference sites. Concentrations of $\mathrm{Pb}, \mathrm{Zn}$, and $\mathrm{Ni}$ were highest in detritus and were generally higher in macroinvertebrates compared with stonerollers or crayfish. Metal concentrations in the West Fork were generally lower than those in the Bee Fork. Concentrations of $\mathrm{Pb}$ and $\mathrm{Cd}$ in fish; $\mathrm{Zn}$ in invertebrates, and $\mathrm{Zn}$ in surface water were not significantly different among the three groups of sites in the West Fork (Table S-3).

Mean concentrations of metals in crayfish at day 0 were: $\mathrm{Pb}$ $(6.0 \pm 0.4 \mu \mathrm{g} / \mathrm{g}$ dry weight), $\mathrm{Zn}(81 \pm 0.3 \mu \mathrm{g} / \mathrm{g}$ dry weight $), \mathrm{Cd}$ $(0.16 \pm 0.2 \mu \mathrm{g} / \mathrm{g}$ dry weight), Ni $(4.0 \pm 0.7 \mu \mathrm{g} / \mathrm{g}$ dry weight), and Co $(2.0 \pm 0.4 \mu \mathrm{g} / \mathrm{g}$ dry weight). Caged crayfish rapidly accumulated all metals at all mining sites (Fig. 6). Metal concentrations in caged crayfish at SC2 continued to increase throughout the exposure; however, they did not at WF3 or BF3. Metal concentrations in caged crayfish on day 28 at reference and downstream sites were generally lower than concentrations in crayfish stocked into cages on day 0 . Concentrations of metals in caged crayfish at day 28 were comparable to those in wild crayfish at all sites except at SC2, where metal concentrations in caged crayfish were greater than the single large wild crayfish collected at SC2.
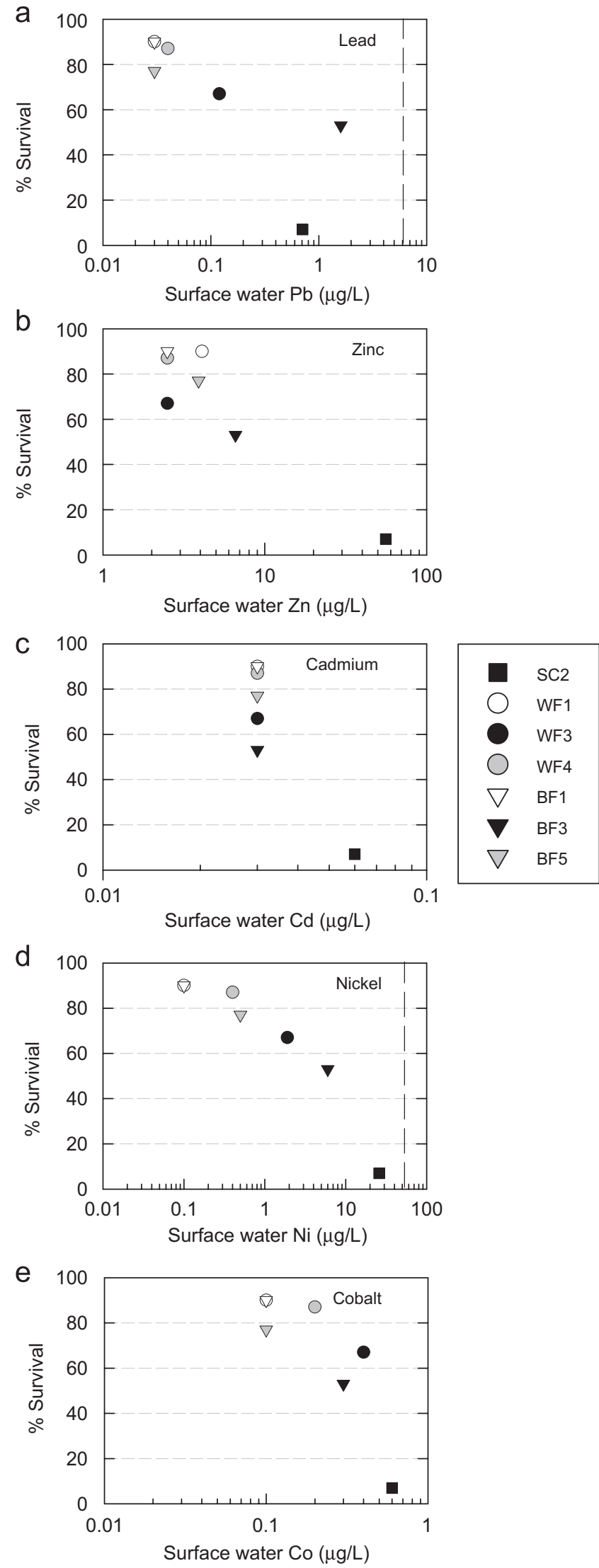

Fig. 4. Relationship between mean percent (\%) survival of caged Orconectes hylas on day 28 and mean metal concentrations in surface water at sampling sites: (a) lead; (b) zinc; (c) cadmium; (d) nickel; and (e) cobalt. Dashed lines are mean chronic water quality criteria for the sample sites. 


\subsection{Correlation analyses}

Carapace length and wet weight of caged crayfish were negatively correlated with $\mathrm{Zn}$ concentrations in stonerollers (Table S-4). Carapace length and wet weight of caged crayfish

Table 3

Number $(n)$, carapace length $(\mathrm{CL})$, and wet weight (means with standard error in parenthesis) of wild Orconectes hylas collected at sampling sites on days 0 and 28 of the in-situ exposure.

\begin{tabular}{|c|c|c|c|}
\hline Day/site & $n$ & $\mathrm{CL}(\mathrm{mm})$ & Wet wt. (g) \\
\hline \multicolumn{4}{|l|}{ Day 0} \\
\hline \multicolumn{4}{|l|}{ Reference sites } \\
\hline WF1 & 30 & $10.1(0.3) a$ & $0.26(0.03) \mathrm{a}$ \\
\hline $\mathrm{BF} 1$ & 35 & $9.5(0.2) \mathrm{a}$ & $0.21(0.02) \mathrm{a}$ \\
\hline Group mean & & $9.8(0.3) \mathrm{A}$ & $0.23(0.02) \mathrm{A}$ \\
\hline \multicolumn{4}{|l|}{ Mining sites } \\
\hline $\mathrm{SC} 2$ & 0 & - & - \\
\hline WF3 & 1 & $5.4(-) \mathrm{a}$ & $0.03(-) \mathrm{a}$ \\
\hline BF3 & 32 & $9.2(0.3) \mathrm{a}$ & $0.18(0.01) \mathrm{a}$ \\
\hline Group mean & & 7.3 (1.9) B & $0.11(0.08) \mathrm{B}$ \\
\hline \multicolumn{4}{|c|}{ Downstream sites } \\
\hline WF4 & 30 & $9.4(0.3) \mathrm{a}$ & $0.22(0.03) \mathrm{a}$ \\
\hline BF5 & 43 & $7.1(0.2)$ a & $0.08(0.01) \mathrm{a}$ \\
\hline & & $8.2(0.1) \mathrm{A}$ & $0.15(0.07) \mathrm{A}$ \\
\hline \multicolumn{4}{|l|}{ Day 28} \\
\hline \multicolumn{4}{|l|}{ Reference sites } \\
\hline WF1 & 30 & $12.9(0.3)$ a & $0.58(0.04) \mathrm{a}$ \\
\hline BF1 & 37 & $12.0(0.4) \mathrm{a}$ & $0.47(0.04) \mathrm{a}$ \\
\hline Group mean & & $12.5(0.4) \mathrm{A}$ & $0.53(0.05) \mathrm{A}$ \\
\hline \multicolumn{4}{|l|}{ Mining sites } \\
\hline $\mathrm{SC} 2$ & 1 & $35.0(-)$ & $12.1(-)$ \\
\hline WF3 & 12 & $12.2(0.4) \mathrm{a}$ & $0.48(0.05) \mathrm{a}$ \\
\hline BF3 & 2 & $12.3(0.2) \mathrm{b}$ & $0.34(0.05) \mathrm{a}$ \\
\hline Group mean & & $12.2(0.02) \mathrm{A}$ & $0.41(0.07) \mathrm{B}$ \\
\hline \multicolumn{4}{|c|}{ Downstream sites } \\
\hline WF4 & 18 & $13.2(0.3) a$ & $0.56(0.04) a$ \\
\hline BF5 & 30 & $12.3(0.3) \mathrm{a}$ & $0.53(0.05) \mathrm{a}$ \\
\hline Group mean & & $12.7(0.5) \mathrm{A}$ & $0.55(0.02) \mathrm{A}$ \\
\hline
\end{tabular}

Sites with the same lower case letter and groups of sites with the same capital letter are not significantly different for each test day $(P<0.05)$ were negatively correlated with SRP, and CL was negatively correlated with TP (Table S-5).

Mean percent survival of caged crayfish was negatively correlated with most metal concentrations in surface water, detritus, macroinvertebrates, stonerollers, and caged crayfish (Table 8). Biomass of caged crayfish was negatively correlated with $\mathrm{Zn}$ concentrations in stonerollers and Co concentrations in caged crayfish. Concentrations of $\mathrm{Pb}, \mathrm{Zn}, \mathrm{Ni}$, and $\mathrm{Co}$ in caged crayfish and all environmental matrixes were highly inter-correlated (Table 8). Lead concentrations in caged crayfish were positively correlated with $\mathrm{Pb}, \mathrm{Zn}$, and Ni concentrations in wild crayfish (Table 8). Zinc concentrations in caged crayfish were positively correlated with Co concentrations in wild crayfish. Survival of caged crayfish was negatively correlated with $\mathrm{NH}_{3}, \mathrm{NO}_{2} / \mathrm{NO}_{3}, \mathrm{TN}$, conductivity, hardness, and sulfate (Table S-5). Biomass of caged crayfish was negatively correlated with DOC (Table S-5).

Wet weight of wild crayfish was correlated with Co concentrations in wild crayfish (Table S-4); however, CL and wet weight of wild crayfish were not significantly correlated with any water quality parameter or nutrient concentration (Table S-5). There were fewer significant correlations between metal concentrations in wild crayfish and the other samples collected at the sites; however, concentrations of $\mathrm{Pb}$ in wild crayfish were significantly correlated with most metals in all sample types analyzed (Table 8). Zinc concentrations in wild crayfish were significantly correlated with $\mathrm{Pb}, \mathrm{Zn}$, and $\mathrm{Cd}$ concentrations in detritus, and with $\mathrm{Zn}$ concentrations in macroinvertebrates. Nickel concentrations in wild crayfish were correlated with $\mathrm{Zn}$ concentrations in macroinvertebrates, and $\mathrm{Pb}, \mathrm{Zn}$, and $\mathrm{Cd}$ concentrations in detritus.

Ammonia, $\mathrm{NO}_{2} / \mathrm{NO}_{3}$, TN, conductivity, hardness, sulfate, and $\mathrm{Ni}$ concentrations in surface water were all significantly correlated (Table S-6). Soluble reactive phosphorous (SRP) was negatively correlated with dissolved oxygen; dissolved organic carbon was negatively correlated with $\mathrm{pH}$; and temperature was negatively correlated with Co concentrations in surface water. Hardness was also significantly correlated with $\mathrm{Pb}, \mathrm{Ni}$, and Co concentrations in surface water. Lead concentrations in surface water were significantly correlated with Co concentrations in surface water, as were $\mathrm{Ni}$ and $\mathrm{Co}$ concentrations in surface water.

\section{Discussion}

We documented decrease survival of caged crayfish at sites directly downstream $(0.4-3.7 \mathrm{~km})$ of mining sites. Survival and

Table 4

Water quality (means with standard error in parenthesis) of surface water at sampling sites.

\begin{tabular}{|c|c|c|c|c|c|c|c|c|}
\hline Site & Temp $\left({ }^{\circ} \mathrm{C}\right)$ & $\mathrm{PH}(\mathrm{SU})$ & Cond $(\mu \mathrm{s} / \mathrm{cm})$ & $\mathrm{DO}(\mathrm{mg} / \mathrm{L})$ & Alk $\left(\mathrm{mg} / \mathrm{L}\right.$ as $\left.\mathrm{CaCO}_{3}\right)$ & $\operatorname{Hard}\left(\mathrm{mg} / \mathrm{L}\right.$ as $\left.\mathrm{CaCO}_{3}\right)$ & Turb (NTU) & Sulfate $(\mathrm{mg} / \mathrm{L})$ \\
\hline \multicolumn{9}{|l|}{ Reference sites } \\
\hline WF1 & $23.6(0.6) a$ & $8.04(0.03) a b$ & $344(5) \mathrm{e}$ & $7.8(0.5) \mathrm{a}$ & $182(3) \mathrm{a}$ & $183(3) d$ & $0.60(0.04) \mathrm{a}$ & $0.3(0.2) \mathrm{e}$ \\
\hline BF1 & $23.1(1.4) b$ & $7.84(0.09) \mathrm{c}$ & $282(6) \mathrm{f}$ & $6.3(0.4) b$ & $143(3) \mathrm{c}$ & $145(2) \mathrm{e}$ & $0.50(0.04) \mathrm{a}$ & $1(0.3) \mathrm{e}$ \\
\hline Group mean & $23.4(0.7) \mathrm{A}$ & $7.94(0.06) \mathrm{B}$ & 313 (11) C & $7.1(0.4) \mathrm{B}$ & $162(8) A$ & $164(7) \mathrm{C}$ & $0.55(0.03) \mathrm{B}$ & $0.6(0.2) \mathrm{C}$ \\
\hline \multicolumn{9}{|l|}{ Mining sites } \\
\hline $\mathrm{SC} 2$ & $25.8(0.5) a$ & $7.94(0.04) b c$ & $858(31) a$ & $8.0(0.2) \mathrm{a}$ & $117(3) d$ & 409 (11) a & $0.50(0.04) \mathrm{a}$ & $304(10) \mathrm{a}$ \\
\hline WF3 & $24.6(0.9) \mathrm{a}$ & $8.09(0.03) \mathrm{a}$ & 418 (7) cd & $8.4(0.3) \mathrm{a}$ & 170 (3) b & $212(3) c$ & $0.40(0.05) \mathrm{a}$ & $53(3) d$ \\
\hline BF3 & $24.2(0.9) \mathrm{a}$ & $8.01(0.05) a b$ & $592(15) \mathrm{b}$ & $8.4(0.1) \mathrm{a}$ & $143(2) c$ & 247 (5) b & $0.40(0.06) \mathrm{a}$ & $129(6) \mathrm{b}$ \\
\hline Group mean & $24.9(0.5) \mathrm{A}$ & $8.01(0.03) \mathrm{A}$ & $623(42) \mathrm{A}$ & $8.3(0.1) \mathrm{A}$ & 143 (7) A & $289(26) \mathrm{A}$ & $0.45(0.03) \mathrm{A}$ & $162(32) \mathrm{A}$ \\
\hline \multicolumn{9}{|c|}{ Downstream sites } \\
\hline WF4 & $24.3(0.4) \mathrm{a}$ & $8.10(0.04)$ a & $395(2) d$ & $8.3(0.1)$ a & $165(2) b$ & $198(1) \mathrm{c}$ & $0.50(0.12) \mathrm{a}$ & $42(1) \mathrm{d}$ \\
\hline BF5 & $22.9(0.8) \mathrm{a}$ & $8.05(0.04) a b$ & $446(4) c$ & $8.2(0.1)$ a & $141(1) \mathrm{c}$ & 199 (1) c & $0.40(0.02) \mathrm{a}$ & $80(1) c$ \\
\hline Group mean & $23.6(0.5) \mathrm{A}$ & $8.08(0.03) \mathrm{A}$ & 420 (9) B & $8.3(0.1) \mathrm{A}$ & $152(5) \mathrm{B}$ & 199 (1) B & $0.44(0.05) \mathrm{A}$ & $64(8) \mathrm{B}$ \\
\hline
\end{tabular}

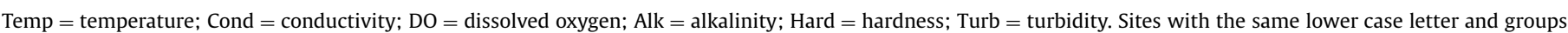
of sites with the same capital letter are not significantly different $(P<0.05)$. 
Table 5

Nutrient concentrations (means with standard error in parenthesis) of surface waters at sampling sites.

\begin{tabular}{|c|c|c|c|c|c|c|}
\hline Site & $\mathrm{NH}_{3}(\mathrm{mg} \mathrm{N} / \mathrm{L})$ & $\mathrm{SRP}(\mu \mathrm{g} \mathrm{P} / \mathrm{L})$ & $\mathrm{NO}_{2} / \mathrm{NO}_{3}(\mathrm{mg} \mathrm{N} / \mathrm{L})$ & $\mathrm{DOC}(\mathrm{mg} \mathrm{C} / \mathrm{L})$ & $\mathrm{TN}(\mathrm{mg} \mathrm{N} / \mathrm{L})$ & $\mathrm{TP}(\mu \mathrm{g} \mathrm{P} / \mathrm{L})$ \\
\hline \multicolumn{7}{|l|}{ Reference sites } \\
\hline WF1 & $0.01(0.002) \mathrm{b}$ & $0.5(0.3) \mathrm{a}$ & $0.04(0.01) \mathrm{d}$ & $0.59(0.04)$ bc & $0.10(0.01) c$ & $3.7(0.6) a b$ \\
\hline BF1 & $0.01(0.002) b$ & $0.8(0.4) \mathrm{a}$ & $0.07(0.01) \mathrm{d}$ & $0.90(0.07) \mathrm{a}$ & $0.20(0.01) \mathrm{c}$ & $2.4(0.5) a b$ \\
\hline Group mean & $0.01(0.002) \mathrm{B}$ & $0.6(0.3) \mathrm{A}$ & $0.06(0.01) \mathrm{C}$ & $0.75(0.06) \mathrm{A}$ & $0.12(0.01) \mathrm{B}$ & $2.9(0.4) \mathrm{A}$ \\
\hline \multicolumn{7}{|l|}{ Mining sites } \\
\hline $\mathrm{SC} 2$ & $0.06(0.01) \mathrm{a}$ & $0.3(0.2) \mathrm{a}$ & $1.2(0.09) \mathrm{a}$ & $0.91(0.06) \mathrm{a}$ & $1.30(0.08) a$ & $4.4(0.4) \mathrm{a}$ \\
\hline WF3 & $0.01(0.002) \mathrm{b}$ & $0.2(0.1) \mathrm{a}$ & $0.13(0.01) \mathrm{cd}$ & $0.60(0.02) \mathrm{bc}$ & $0.20(0.02) \mathrm{c}$ & $2.8(0.8) b$ \\
\hline BF3 & $0.01(0.003) \mathrm{b}$ & $0 \mathrm{c}$ & $0.51(0.02) \mathrm{b}$ & $0.69(0.06) b$ & $0.50(0.03) b$ & $2.0(0.6)$ a \\
\hline Group mean & $0.03(0.01) \mathrm{A}$ & $0.1(0.1) \mathrm{B}$ & $0.61(0.10) \mathrm{A}$ & $0.73(0.04) \mathrm{A}$ & $0.68(0.10) \mathrm{A}$ & $3.1(0.4) \mathrm{A}$ \\
\hline \multicolumn{7}{|c|}{ Downstream sites } \\
\hline WF4 & $0.01(0.003) \mathrm{b}$ & $0 \mathrm{a}$ & $0.08(0.01) \mathrm{d}$ & $0.57(0.03) \mathrm{c}$ & $0.10(0.01) c$ & $2.0(0.2) b$ \\
\hline BF5 & $0.01(0.003) \mathrm{b}$ & $0.2(0.2) \mathrm{a}$ & $0.19(0.01) c$ & $0.50(0.04) \mathrm{c}$ & $0.20(0.01) \mathrm{c}$ & $2.6(1.2) a b$ \\
\hline Group mean & $0.01(0.001) \mathrm{B}$ & $0.1(0.1) \mathrm{B}$ & $0.14(0.02) \mathrm{B}$ & $0.53(0.03) \mathrm{B}$ & $0.17(0.02) \mathrm{B}$ & $3.1(0.4) \mathrm{A}$ \\
\hline
\end{tabular}

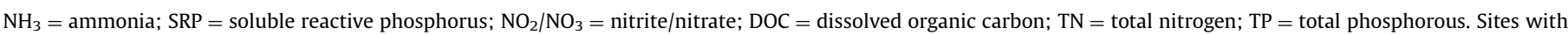
the same lower case letter and groups of sites with the same capital letter are not significantly different $(P<0.05)$.

Table 6

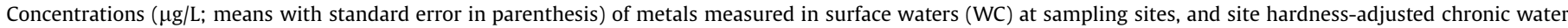
quality criteria (WQC).

\begin{tabular}{|c|c|c|c|c|c|c|c|c|c|}
\hline \multirow[t]{2}{*}{ Site } & \multicolumn{2}{|l|}{ Lead } & \multicolumn{2}{|l|}{ Zinc } & \multicolumn{2}{|l|}{ Cadmium } & \multicolumn{2}{|l|}{ Nickel } & \multirow{2}{*}{$\begin{array}{l}\text { Cobalt } \\
\text { WC }\end{array}$} \\
\hline & WC & WQC & WC & WQC & WC & WQC & WC & WQC & \\
\hline \multicolumn{10}{|l|}{ Reference sites } \\
\hline WF1 & $0.03(0) c$ & 4.9 & $4.1(2) b$ & 197 & $0.03(0) \mathrm{b}$ & 0.37 & $0.13(0) \mathrm{c}$ & 46 & $0.09(0.01) \mathrm{de}$ \\
\hline BF1 & $0.03(0) c$ & 3.8 & $2.5(0) \mathrm{b}$ & 162 & $0.03(0) \mathrm{b}$ & 0.32 & $0.13(0) c$ & 38 & $0.14(0.01) \mathrm{d}$ \\
\hline Group mean & $0.03(0) \mathrm{B}$ & 4.4 & 3.3 (1) B & 180 & $0.03(0) \mathrm{A}$ & 0.35 & $0.13(0) \mathrm{B}$ & 42 & $0.12(0.01) \mathrm{B}$ \\
\hline \multicolumn{10}{|l|}{ Mining sites } \\
\hline $\mathrm{SC} 2$ & $0.71(0.02) b$ & 11.3 & $56(5) \mathrm{a}$ & 390 & $0.06(0.02) \mathrm{a}$ & 0.65 & $26(2) a$ & 90 & $0.64(0.05) \mathrm{a}$ \\
\hline WF3 & $0.12(0.01) \mathrm{c}$ & 5.7 & $2.5(0) \mathrm{b}$ & 223 & $0.03(0) \mathrm{b}$ & 0.41 & $1.9(0.01) \mathrm{c}$ & 52 & $0.39(0.02) b$ \\
\hline BF3 & $1.59(0.06) \mathrm{a}$ & 6.8 & $6.6(0.2) \mathrm{b}$ & 254 & $0.03(0) \mathrm{b}$ & 0.46 & $6.0(0.01) \mathrm{b}$ & 59 & $0.28(0.01) c$ \\
\hline Group mean & $0.86(0.18) \mathrm{A}$ & 7.9 & 20 (7) A & 289 & $0.03(0.01) \mathrm{A}$ & 0.51 & $11(3) \mathrm{A}$ & 67 & $0.43(0.05) \mathrm{A}$ \\
\hline \multicolumn{10}{|c|}{ Downstream sites } \\
\hline WF4 & $0.04(0.01) c$ & 5.3 & $2.5(0) \mathrm{b}$ & 211 & $0.03(0) \mathrm{b}$ & 0.40 & $0.40(0) c$ & 49 & $0.15(0.01) d$ \\
\hline BF5 & $0.03(0) \mathrm{c}$ & 5.3 & $3.9(1) b$ & 211 & $0.03(0) \mathrm{b}$ & 0.40 & $0.50(0) \mathrm{c}$ & 49 & $0.12(0.01) \mathrm{d}$ \\
\hline Group mean & $0.04(0.01) \mathrm{B}$ & 5.3 & 3.3 (1) B & 211 & $0.03(0) \mathrm{A}$ & 0.40 & $0.46(0.02) \mathrm{B}$ & 49 & $0.13(0.01) \mathrm{B}$ \\
\hline
\end{tabular}

Sites with the same lower case letter and groups of sites with the same capital letter are not significantly different $(P<0.05)$.

biomass of caged crayfish were significantly lower at mining sites than reference or downstream sites, and survival was negatively correlated with metal concentrations in surface water, detritus, macroinvertebrates, stonerollers, and whole crayfish. Survival was also negatively correlated with several water quality parameters. Our study supports previous results which found reduced densities of $O$. hylas populations in riffle habitats, and elevated metals concentrations ( $\mathrm{Pb}, \mathrm{Zn}, \mathrm{Cd}, \mathrm{Ni}$, and $\mathrm{Co}$ ) in $\mathrm{O}$. hylas at sites directly downstream of mining in the Black River watershed (Allert et al., 2008). Metal concentrations in detritus and biota at mining sites in this study were comparable to those of Besser et al. (2006), and decreased with distance from mining sites. Alikhan et al. (1990) also reported an inverse relationship between distance from a contaminant source and metal concentrations in crayfish. Conductivity, hardness, sulfate, and nitrogen ions often are elevated below mining sites (Gray, 1998; Tiwary, 2001), and may be useful in indicating the extent of mining impacts. Finally, in-situ testing of crayfish was an important tool for demonstrating that absence of crayfish populations below mining sites was the result of metal exposure as opposed to habitat loss due to physical impairment by mine waste (e.g., sedimentation by mine tailings).

Although no toxicity studies have been conducted with juvenile $O$. hylas in single-metal exposures, previous studies have shown several species of crayfish to be relatively sensitive to metals, and that juvenile crayfish are more sensitive than adult crayfish. Wigginton and Birge (2007) calculated 96-h median lethal concentrations $\left(\mathrm{LC}_{50}\right)$ of $\mathrm{Cd}$ to six species of crayfish (Cambaridae) with a mean $\mathrm{LC}_{50}$ of $1510 \mu \mathrm{g} \mathrm{Cd} / \mathrm{L}$ for adult crayfish and of $111 \mu \mathrm{g} \mathrm{Cd} / \mathrm{L}$ for juvenile crayfish at a water hardness of approximately $45 \mathrm{mg} / \mathrm{L}$ as $\mathrm{CaCO}_{3}$. Other studies (Lindhjem and Bennet-Chambers, 2002; Mirenda, 1986a, b; Naqvi and Howell, 1993) have also reported lethal concentrations that are greater than the metal concentrations measured in surface waters from our study streams; however, these laboratory studies were short in duration and conducted with different species and sizes of crayfish. Thorp et al. (1979) reported that long-term exposure to 5 
Table 7

Metal concentrations ( $\mu \mathrm{g} / \mathrm{g}$ dry weight; means with standard error in parenthesis) in detritus and biota at sampling sites.

\begin{tabular}{|c|c|c|c|c|c|}
\hline Metal and site(s) & Detritus $^{\mathrm{a}}$ & Macro-invertebrates $^{\mathrm{a}}$ & Stonerollers $^{\mathrm{b}}$ & Wild crayfish ${ }^{c}$ & 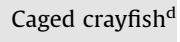 \\
\hline \multicolumn{6}{|l|}{ Lead } \\
\hline \multicolumn{6}{|l|}{ Reference sites } \\
\hline WF1 & $11(2) b$ & $2.0(1) \mathrm{c}$ & $2.6(0.1) \mathrm{d}$ & $0.53(-)$ & $1.2(0.2) \mathrm{b}$ \\
\hline BF1 & $7.2(1) b$ & $1.0(0.2) \mathrm{c}$ & $4.3(1) \mathrm{cd}$ & $0.42(-)$ & $0.99(0.2) \mathrm{b}$ \\
\hline Group mean & 8.9 (1) B & $1.5(0.5) \mathrm{B}$ & 3.4 (1) B & $0.48(0.1) \mathrm{B}$ & $1.1(0.2) \mathrm{B}$ \\
\hline \multicolumn{6}{|l|}{ Mining sites } \\
\hline $\mathrm{SC} 2$ & $650(82) a$ & $81(12) b$ & $42(2) a$ & $14(-)$ & $37^{e}(7) a$ \\
\hline WF3 & $143(30) \mathrm{b}$ & $11(2) \mathrm{c}$ & $8.9^{c}(-) c$ & $1.7(-)$ & $6.4(1) b$ \\
\hline BF3 & $567(63) a$ & $114(15) \mathrm{a}$ & 33 (3) b & $42(-)$ & $37(4) \mathrm{a}$ \\
\hline Group mean & $453(74) \mathrm{A}$ & 69 (14) A & $32(6) A$ & 15 (9) A & $26(4) \mathrm{A}$ \\
\hline \multicolumn{6}{|l|}{ Downstream sites } \\
\hline WF4 & $54(8) b$ & $5.3(1) c$ & $4.6(1) \mathrm{cd}$ & $1.5(-)$ & $2.8(0.3) b$ \\
\hline BF5 & $32(2) b$ & $8.1(1) c$ & $6.2(1) \mathrm{cd}$ & $2.0(-)$ & $2.6(0.3) \mathrm{b}$ \\
\hline Group mean & 41 (5) B & 6.9 (1) B & 5.6 (1) B & $1.7(0.2) \mathrm{B}$ & $2.7(0.2) \mathrm{B}$ \\
\hline \multicolumn{6}{|l|}{ Zinc } \\
\hline \multicolumn{6}{|l|}{ Reference sites } \\
\hline WF1 & $26(3) d$ & $100(9) \mathrm{c}$ & $112(4) b$ & $62(-)$ & $64(1) d$ \\
\hline BF1 & $25(1) d$ & $90(9) \mathrm{c}$ & 129 (3) b & $57(-)$ & $68(1) \mathrm{cd}$ \\
\hline Group mean & 25 (1) B & 95 (6) B & 120 (5) B & 60 (3) A & 66 (1) B \\
\hline \multicolumn{6}{|l|}{ Mining sites } \\
\hline $\mathrm{SC} 2$ & 2288 (309) a & 392 (35) a & 317 (31) a & 73 & $236^{\mathrm{e}}(10) \mathrm{a}$ \\
\hline WF3 & 529 (27) bc & 162 (41) bc & $148^{\mathrm{c}}(-) \mathrm{b}$ & 64 & $105(5) b$ \\
\hline BF3 & $693(15) b$ & 196 (28) b & 108 (15) b & 83 & 97 (3) b \\
\hline Group mean & $1170(257) \mathrm{A}$ & $250(36) \mathrm{A}$ & $200(50) \mathrm{A}$ & $71(5) \mathrm{A}$ & 146 (16) A \\
\hline \multicolumn{6}{|l|}{ Downstream sites } \\
\hline WF4 & $234(11) \mathrm{cd}$ & 151 (44) bc & $93(7) \mathrm{b}$ & $79(-)$ & $68(1) \mathrm{cd}$ \\
\hline BF5 & $129(5) \mathrm{d}$ & 146 (14) bc & $102(13) \mathrm{b}$ & $65(-)$ & $68(3) \mathrm{cd}$ \\
\hline Group mean & $174(22) \mathrm{B}$ & 148 (18) B & 98 (8) B & $72(7) \mathrm{A}$ & 68 (1) B \\
\hline \multicolumn{6}{|l|}{ Cadmium } \\
\hline \multicolumn{6}{|l|}{ Reference sites } \\
\hline WF1 & $0.32(0.02) b$ & $0.81(0.3) b c$ & $0.1(0.02)$ de & $0.75(-)$ & $0.60(0.04) b c$ \\
\hline BF1 & $0.27(0.01) b$ & $0.72(0.1) \mathrm{cd}$ & $0.3(0.01) a$ & $0.77(-)$ & $0.56(0.03) b c$ \\
\hline Group mean & $0.30(0.02) \mathrm{B}$ & $0.77(0.5) \mathrm{A}$ & $0.2(0.04) \mathrm{A}$ & $0.76(0.01) \mathrm{A}$ & $0.57(0.02) \mathrm{B}$ \\
\hline \multicolumn{6}{|c|}{ Cadmium (continued) } \\
\hline \multicolumn{6}{|c|}{ Mining sites } \\
\hline $\mathrm{SC} 2$ & $3.6(1) \mathrm{a}$ & $1.2(0.1) \mathrm{ab}$ & $0.2(0.01) a b$ & $0.78(-)$ & $2.1^{\mathrm{e}}(0.2) \mathrm{a}$ \\
\hline WF3 & $0.91(0.1) b$ & $0.32(0.1) \mathrm{d}$ & $0.1^{\mathrm{c}}(-)$ de & $1.4(-)$ & $0.32(0.02) \mathrm{cd}$ \\
\hline BF3 & $1.3(0.04) b$ & $1.4(0.3) \mathrm{a}$ & $0.2(0.01) \mathrm{cd}$ & $0.41(-)$ & $0.53(0.1) b c$ \\
\hline Group mean & $1.9(0.4) \mathrm{A}$ & $0.97(0.2) \mathrm{A}$ & $0.2(0.02) \mathrm{A}$ & $1.0(0.25) \mathrm{A}$ & $0.98(0.2) \mathrm{A}$ \\
\hline \multicolumn{6}{|l|}{ Downstream sites } \\
\hline WF4 & $0.56(0.1) b$ & $0.41(0.1) \mathrm{cd}$ & $0.1(0.01)$ e & $0.54(-)$ & $0.25(0.03) d$ \\
\hline BF5 & $0.53(0.03) \mathrm{b}$ & $1.2(0.03) a b$ & $0.2(0.01) b c$ & $0.70(-)$ & $0.76(0.1) \mathrm{b}$ \\
\hline Group mean & $0.54(0.03) \mathrm{B}$ & $0.90(0.2) \mathrm{A}$ & $0.2(0.02) \mathrm{A}$ & $0.62(0.08) \mathrm{A}$ & $0.50(0.1) \mathrm{B}$ \\
\hline \multicolumn{6}{|l|}{ Nickel } \\
\hline \multicolumn{6}{|l|}{ Reference sites } \\
\hline WF1 & $8.5(1) d$ & $2.3(1) c$ & $2.0(0.02)$ de & $1.1(-)$ & $1.2(0.04) c$ \\
\hline BF1 & $12(0.4) d$ & $2.3(0.4) \mathrm{c}$ & $1.2(0.1) \mathrm{e}$ & $1.1(-)$ & $1.5(0.1) \mathrm{c}$ \\
\hline Group mean & 10 (1) B & $2.3(0.4) \mathrm{B}$ & $1.6(0.24) \mathrm{B}$ & $1.1(0.01) \mathrm{A}$ & $1.3(0.1) \mathrm{B}$ \\
\hline \multicolumn{6}{|l|}{ Mining sites } \\
\hline SC2 & $487(62)$ a & 57 (9) a & $19(0.2) \mathrm{a}$ & $4.2(-)$ & $17^{e}(2) a$ \\
\hline WF3 & $124(7) \mathrm{c}$ & 17 (4) bc & $9.5^{c}(-) b$ & $1.2(-)$ & $7.5(0.4) b$ \\
\hline BF3 & $298(8) b$ & $28(6) b$ & $5(0.3) c$ & $16(-)$ & $8.3(1) b$ \\
\hline Group mean & 303 (49) A & $34(6) \mathrm{A}$ & $12(3) \mathrm{A}$ & $5.6(3) \mathrm{A}$ & $11(1) \mathrm{A}$ \\
\hline \multicolumn{6}{|l|}{ Downstream sites } \\
\hline WF4 & $34(2) d$ & $4.0(0.2) \mathrm{c}$ & 2.1 (2) de & $2.1(-)$ & $2.1(0.2) \mathrm{c}$ \\
\hline BF5 & $41(2) d$ & $6.3(1) c$ & $2.7(0.5) \mathrm{d}$ & $2.0(-)$ & $1.9(0.1) \mathrm{c}$ \\
\hline
\end{tabular}


Table 7 (continued)

\begin{tabular}{|c|c|c|c|c|c|}
\hline Metal and site(s) & Detritus $^{a}$ & Macro-invertebrates $^{\mathrm{a}}$ & Stonerollers ${ }^{\mathrm{b}}$ & Wild crayfish $^{\mathrm{c}}$ & Caged crayfish $^{\mathrm{d}}$ \\
\hline Group mean & $38(2) \mathrm{B}$ & $5.3(0.6) \mathrm{B}$ & $2.5(0.3) \mathrm{B}$ & $2.1(0.04) \mathrm{A}$ & $2.0(0.1) \mathrm{B}$ \\
\hline \multicolumn{6}{|l|}{ Cobalt } \\
\hline \multicolumn{6}{|l|}{ Reference sites } \\
\hline WF1 & $8.7(1) c$ & $4.8(2) d$ & $1.4(0.01) \mathrm{d}$ & $0.94(-)$ & $0.87(0.03) \mathrm{c}$ \\
\hline BF1 & $10(1) c$ & $6.4(2) d$ & $1.5(0.1) \mathrm{d}$ & $1.6(-)$ & $1.8(0.1)$ bc \\
\hline Group mean & 9.4 (1) B & 5.6 (1) B & $1.4(0.05) \mathrm{B}$ & $1.3(0.3) \mathrm{A}$ & $1.3(0.1) \mathrm{B}$ \\
\hline \multicolumn{6}{|l|}{ Mining sites } \\
\hline $\mathrm{SC} 2$ & $328(40)$ a & $111(9) \mathrm{a}$ & $26(0.3) \mathrm{a}$ & $11(-)$ & $57^{e}(5) a$ \\
\hline WF3 & $86(8) b$ & $24(6) b c$ & $9.5^{\mathrm{c}}(-) \mathrm{b}$ & $1.4(-)$ & $6.9(1) b$ \\
\hline BF3 & 66 (9) b & $38(9) \mathrm{b}$ & $3.7(0.2) c$ & $8.2(-)$ & $5.2(1) \mathrm{bc}$ \\
\hline Group mean & $160(38) \mathrm{A}$ & $58(12) \mathrm{A}$ & $14(5) \mathrm{A}$ & $5.5(2) \mathrm{A}$ & $23(6) \mathrm{A}$ \\
\hline \multicolumn{6}{|l|}{ Downstream sites } \\
\hline WF4 & $18(0.3) \mathrm{c}$ & $9.9(5) \mathrm{cd}$ & $1.6(0.2) \mathrm{d}$ & $1.6(-)$ & $1.5(0.1) b c$ \\
\hline BF5 & $8.9(1) c$ & $4.9(1) \mathrm{d}$ & $1.1(0.2) d$ & $0.96(-)$ & $0.79(0.1) \mathrm{c}$ \\
\hline Group mean & $13(2) \mathrm{B}$ & $7.0(2) \mathrm{B}$ & $1.3(0.2) \mathrm{B}$ & $1.3(0.3) \mathrm{A}$ & $1.1(0.1) \mathrm{B}$ \\
\hline
\end{tabular}

Sites with the same lower case letter and groups of sites with the same capital letter are not significantly different $(P<0.05)$.

a $n=4$.

${ }^{\mathrm{b}} n=2$; Campostoma oligolepis.

${ }^{\text {c }} n=1$.

${ }^{\mathrm{d}} n=6$.

e $n=7$.

and $10 \mu \mathrm{g} \mathrm{Cd} / \mathrm{L}$ completely eliminated a crayfish population in an artificial stream. In addition, toxicity of metals to crayfish has been shown to be higher just after molting due to the high permeability of the soft carapace (Knowlton et al., 1983; Wigginton and Birge, 2007). Therefore, tests that include this sensitive life stage are likely to demonstrate greater sensitivity (e.g., Kunz et al., 2005).

None of the metals in our study exceeded chronic WQC at any of the study sites; however, reduced survival of $O$. hylas may be most associated with $\mathrm{Ni}$ concentrations, due to the bioavailability of $\mathrm{Ni}$ in surface and pore waters (Besser et al., 2008; Brumbaugh et al., 2007) or reflect the cumulative action of a mixture of metals. Results from our study indicate that $O$. hylas are highly sensitive to chronic exposure to metals associated with $\mathrm{Pb}$ mining. These results are consistent with findings of laboratory studies reported by Kunz et al. (2005), who compared the sensitivity of four aquatic taxa to chronic toxicity of a five-metal mixture ( $\mathrm{Pb}$, $\mathrm{Zn}, \mathrm{Cd}, \mathrm{Ni}$, and $\mathrm{Co}$ ), which was based on concentrations measured in sediment pore waters from our study streams. Survival of juvenile $O$. hylas (approximately 30 -d old) was reduced at metal concentrations an order of magnitude lower than those affecting rainbow trout (Onchorhynchus mykiss) and mottled sculpin (Cottus bairdi), fishes that are known to be sensitive to metal toxicity (Besser et al., 2007). The relative sensitivity of crustaceans to metal toxicity was further supported by a laboratory study conducted by Besser et al. (2008) that found toxic effects on survival, growth, and reproduction of $H$. azteca to be significantly correlated with metal concentrations in both sediment and sediment pore water collected from mining sites in the Viburnum Trend.

Previous field studies (Mirenda, 1986a,b; Vijayram and Geraldine, 1996) have shown a significant correlation between metal concentrations in water and those in crayfish. In our study, metal concentrations in caged crayfish were significantly higher at mining sites than at reference sites, and were significantly correlated with surface water metal concentrations; however, there were fewer correlations between metal concentrations in surface water and metal concentration in wild crayfish. Wild crayfish on day 0 were significantly larger than crayfish stocked into cages at all sites except WF3, which may have resulted in fewer molts in wild crayfish during the 28-d exposure. On day 28 , only wild crayfish at WF1, BF1, and the single crayfish collected at SC2 were significantly larger than caged crayfish, which indicated caged crayfish grew faster than wild crayfish, and thus molted more frequently than wild crayfish. More frequent molting may have resulted in higher metal concentrations in caged crayfish due to greater permeability in the carapace after molting (Knowlton et al., 1983; Wigginton and Birge, 2007).

Diet may also influence bioaccumulation of metals in crayfish (Besser et al., 2006; Giesy et al., 1980). Besser et al. (2006) reported strong correlations between $\mathrm{Pb}, \mathrm{Zn}$, and $\mathrm{Cd}$ concentrations in field-collected crayfish, plant material, and benthic organisms in streams within the Viburnum Trend. We also found significant correlations between concentrations of $\mathrm{Pb}, \mathrm{Zn}, \mathrm{Ni}$, and Co in caged crayfish and metal concentrations in detritus, macroinvertebrates, and stonerollers. Although there were fewer significant correlations between metal concentrations in wild crayfish, there were significant correlations among $\mathrm{Pb}, \mathrm{Zn}, \mathrm{Cd}$, and $\mathrm{Ni}$ concentrations in wild crayfish and metal concentrations in detritus, macroinvertebrates, and stonerollers. Caged and wild crayfish may have fed on different food items due to availability, or differences may reflect dietary preference for macroinvertebrates and fish by juvenile crayfish (Parkyn et al., 2001; Whitledge and Rabeni, 1997).

Biomass of caged crayfish was significantly higher at downstream sites than at reference sites and mining sites, and may reflect higher nutrient concentrations. Nutrient concentrations were significantly higher at mining sites, and probably contributed to the development of large algal mats found at some of our mining sites (Gale et al., 1973). These algal mats may provide wild crayfish with additional food resources; however, algae contain high concentrations of metals at sites downstream of mining (Besser et al., 2006), which may increase metal effects.

\section{Conclusions}

These findings suggest that despite the use of efficient extraction technologies and operations that meet environmental 

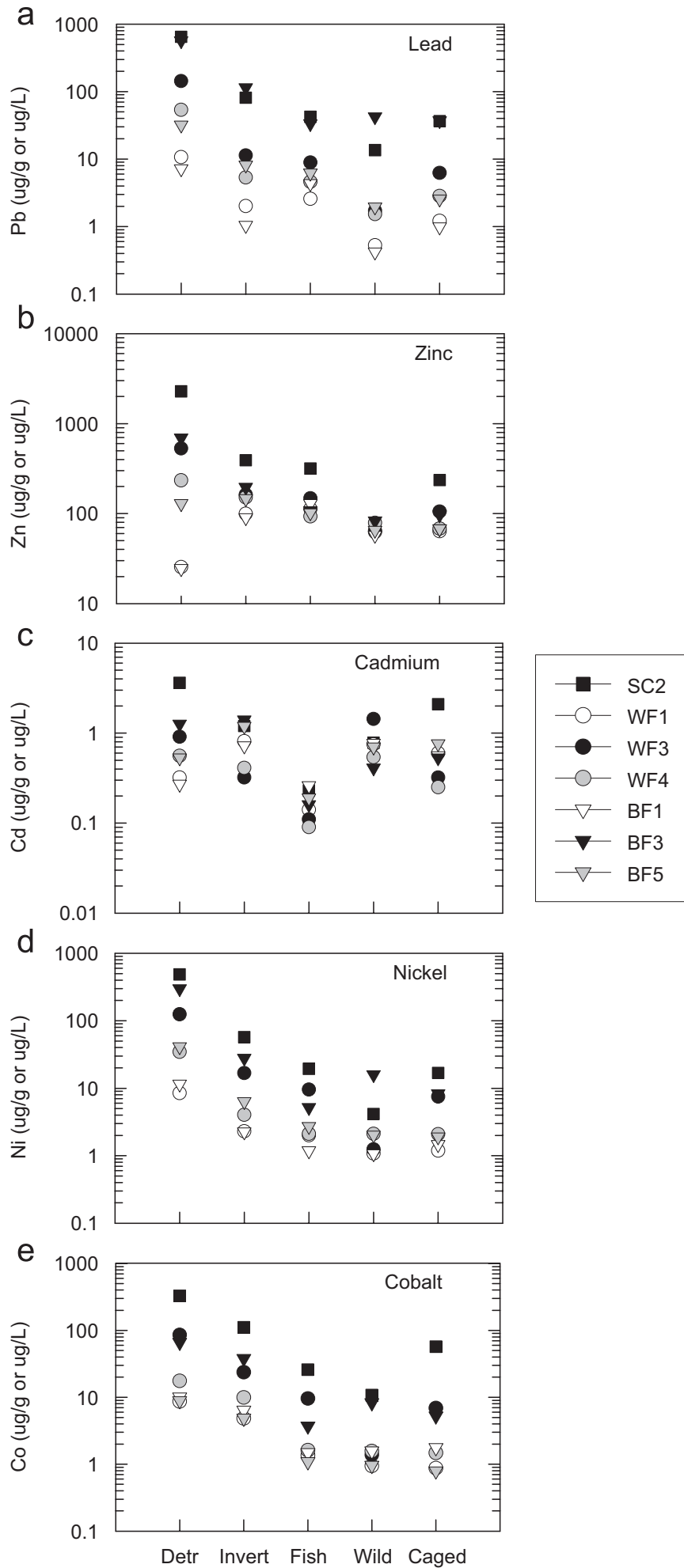

Fig. 5. Metal concentrations in food-web components placed in cages at sampling sites: (a) lead; (b) zinc; (c) cadmium; (d) nickel; and (e) cobalt. Sample types: Detr $=$ detritus; $\quad$ Invert $=$ macroinvertebrates; $\quad$ Fish $=$ stoneroller $\quad$ (Campostoma oligolepis); Wild = wild Orconectes hylas; and Caged = caged 0 . hylas.

regulations, $\mathrm{Pb}-\mathrm{Zn}$ mining in the Viburnum Trend is impacting water quality, metal accumulation in food webs, and $O$. hylas populations of the Black River watershed. Our results indicate that

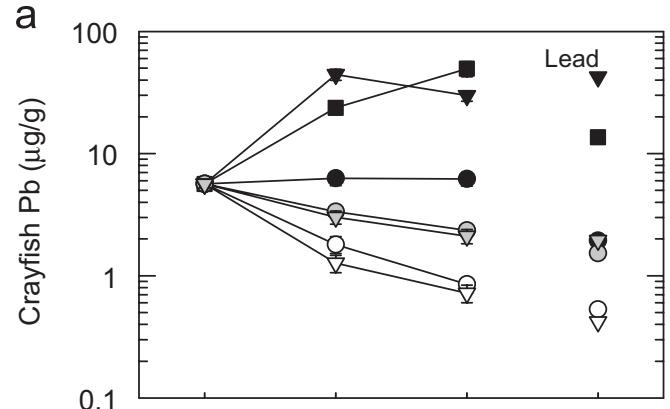

$\mathrm{b}$

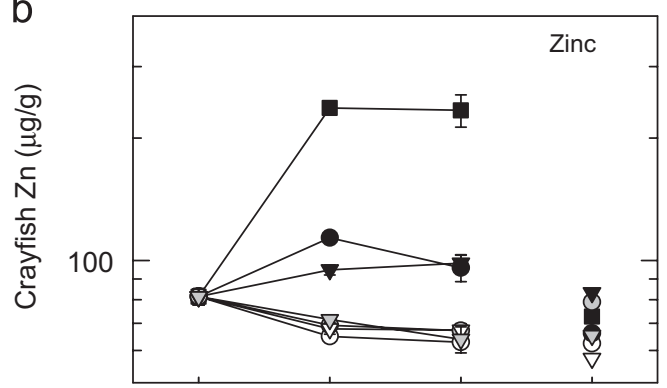

C

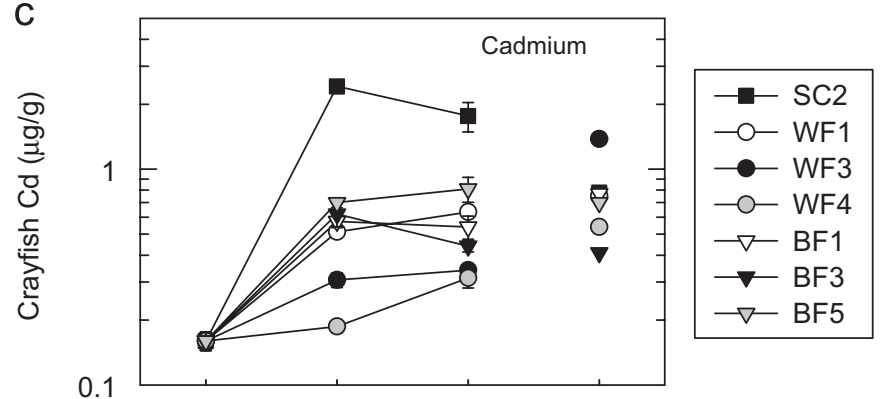

$\mathrm{d}$
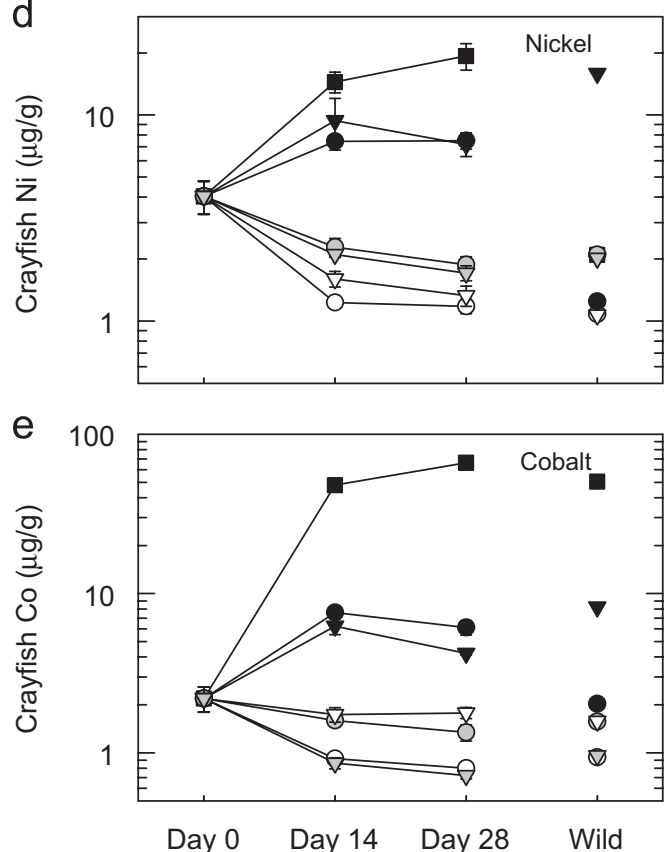

Fig. 6. Mean metal concentrations in caged Orconectes hylas (days 0,14, and 28), and wild 0 . hylas (day 28) at sampling sites: (a) lead; (b) zinc; (c) cadmium; (d) nickel; and (e) cobalt.

metals were the main factor causing the observed toxic effects on 0 . hylas in streams of the Black River watershed, including elevated concentrations of metals in crayfish. Survival and 
Table 8

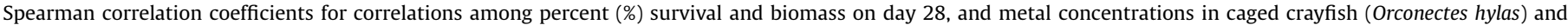
metal concentrations in surface water, detritus, macroinvertebrates, stonerollers (Campostoma oligolepis), and wild crayfish ( 0 . hylas) on day 28.

\begin{tabular}{|c|c|c|c|c|c|c|c|c|c|c|c|c|c|}
\hline \multirow[t]{2}{*}{ Metal } & & \multicolumn{7}{|c|}{ Caged crayfish } & \multicolumn{5}{|c|}{ Wild crayfish } \\
\hline & & Lead & Zinc & Cadmium & Nickel & Cobalt & Biomass & \% Survival & Lead & Zinc & Cadmium & Nickel & Cobalt \\
\hline \multirow[t]{5}{*}{ Lead } & Surface water & 0.93 & 0.85 & -0.19 & 0.85 & 0.78 & -0.44 & -0.86 & 0.64 & 0.70 & -0.34 & 0.70 & 0.58 \\
\hline & Detritus & 1.0 & 0.79 & 0.04 & 0.93 & 0.71 & -0.43 & -0.95 & 0.83 & 0.83 & -0.43 & 0.83 & 0.37 \\
\hline & Macroinvertebrates & 0.93 & 0.71 & 0.07 & 0.82 & 0.57 & -0.36 & -0.95 & 0.94 & 0.77 & -0.37 & 0.77 & 0.26 \\
\hline & Stonerollers & 0.93 & 0.86 & 0.18 & 0.93 & 0.71 & -0.54 & -0.99 & 0.89 & 0.71 & -0.31 & 0.71 & 0.49 \\
\hline & Caged crayfish & - & 0.79 & 0.04 & 0.93 & 0.71 & -0.43 & -0.95 & 0.83 & 0.83 & -0.43 & 0.83 & 0.37 \\
\hline \multirow[t]{5}{*}{ Zinc } & Surface water & 0.56 & 0.37 & 0.67 & 0.30 & 0.26 & -0.30 & -0.58 & 0.52 & 0.39 & -0.58 & 0.39 & -0.03 \\
\hline & Detritus & 1.0 & 0.79 & 0.04 & 0.93 & 0.71 & -0.43 & -0.95 & 0.83 & 0.83 & -0.43 & 0.83 & 0.37 \\
\hline & Macroinvertebrates & 1.0 & 0.79 & 0.04 & 0.93 & 0.71 & -0.43 & -0.95 & 0.83 & 0.83 & -0.43 & 0.83 & 0.37 \\
\hline & Stonerollers & 0.29 & 0.57 & 0.39 & 0.43 & 0.75 & -0.96 & -0.34 & -0.31 & -0.66 & 0.83 & -0.66 & 0.03 \\
\hline & Caged crayfish & 0.79 & - & 0.04 & 0.86 & 0.93 & -0.75 & -0.81 & 0.43 & 0.37 & -0.09 & 0.37 & 0.83 \\
\hline \multirow[t]{5}{*}{ Cadmium } & Surface Water & 0.61 & 0.61 & 0.61 & 0.61 & 0.61 & -0.61 & -0.62 & - & - & - & - & - \\
\hline & Detritus & 1.0 & 0.79 & 0.04 & 0.93 & 0.71 & -0.43 & -0.95 & 0.83 & 0.83 & -0.43 & 0.83 & 0.37 \\
\hline & Macroinvertebrates & 0.39 & 0.32 & 0.61 & 0.14 & 0.07 & -0.11 & -0.49 & 0.49 & 0.37 & -0.66 & 0.37 & 0.14 \\
\hline & Stonerollers & -0.14 & 0.29 & 0.71 & -0.07 & 0.14 & -0.46 & -0.07 & -0.09 & -0.37 & 0.09 & -0.37 & 0.20 \\
\hline & Caged crayfish & 0.04 & 0.04 & - & -0.04 & -0.04 & -0.32 & -0.20 & -0.02 & -0.37 & 0.09 & -0.37 & -0.48 \\
\hline \multirow[t]{5}{*}{ Nickel } & Surface Water & 0.95 & 0.81 & 0.20 & 0.91 & 0.68 & -0.50 & -1.0 & 0.93 & 0.75 & -0.35 & 0.75 & 0.38 \\
\hline & Detritus & 0.93 & 0.86 & 0.18 & 0.93 & 0.71 & -0.54 & -0.99 & 0.89 & 0.71 & -0.31 & 0.71 & 0.49 \\
\hline & Macroinvertebrates & 0.96 & 0.75 & 0.21 & 0.89 & 0.64 & -0.46 & -0.99 & 0.94 & 0.77 & -0.37 & 0.77 & 0.26 \\
\hline & Stonerollers & 0.93 & 0.71 & 0.18 & 0.93 & 0.68 & -0.54 & -0.95 & 0.83 & 0.60 & -0.09 & 0.60 & 0.09 \\
\hline & Caged crayfish & 0.93 & 0.86 & -0.04 & - & 0.82 & -0.57 & -0.91 & 0.66 & 0.60 & -0.09 & 0.60 & 0.43 \\
\hline \multirow[t]{5}{*}{ Cobalt } & Surface Water & 0.86 & 0.93 & -0.11 & 0.96 & 0.93 & -0.68 & -0.83 & 0.43 & 0.43 & 0.03 & 0.43 & 0.60 \\
\hline & Detritus & 0.86 & 0.93 & -0.11 & 0.96 & 0.93 & -0.68 & -0.82 & 0.43 & 0.43 & 0.03 & 0.43 & 0.60 \\
\hline & Macroinvertebrates & 0.89 & 0.96 & -0.07 & 0.93 & 0.89 & -0.61 & -0.86 & 0.54 & 0.60 & -0.26 & 0.60 & 0.77 \\
\hline & Stonerollers & 0.82 & 0.89 & -0.14 & 0.89 & 0.96 & -0.71 & -0.74 & 0.26 & 0.31 & 0.09 & 0.31 & 0.54 \\
\hline & Caged crayfish & 0.71 & 0.93 & -0.04 & 0.82 & - & -0.86 & -0.69 & 0.14 & 0.09 & 0.26 & 0.09 & 0.60 \\
\hline
\end{tabular}

For wild crayfish, no data from SC2 is included. Correlations in boldface are significant $(P<0.05)$.

biomass data from the in-situ toxicity test suggest that recovery of crayfish populations may occur approximately $10 \mathrm{~km}$ downstream of mining sites. The absence of crayfish may have negative effects on organic (e.g., leaves, woody debris) processing, nutrient cycling, and energy transfer in Ozark streams. Crayfish are the predominant prey item of smallmouth bass, an important species sought by recreational anglers in the Ozarks (Mayers, 2003; Weithman, 1991), and other centrarchid fishes in Ozark streams (DiStefano, 2005; Probst et al., 1984). High metal concentrations in centrarchids are likely related to high metal concentrations in crayfish, which could potentially represent a hazard to both wildlife and humans (Schmitt et al., 2006).

\section{Acknowledgments}

Funding for this research was provided by the US Government through the US Geological Survey. We thank the private landowners and the Doe Run Corporation who allowed access to these streams. CERC personnel who assisted included: J. Arms, E. Brunson, J.M. Fairchild (CERC volunteer), K. Grabner, L. Johnson, S. Koppi, T. May, S. Olson, B. Poulton, L. Sappington, D. Stoppler, M. Struckhoff, C. Vishy, M. Walther, D. Whites, and C. Witte. Missouri Department of Conservation personnel who assisted were: T. Boersig, L. Cole, I. Dasho (an AFS Hutton Junior Biologist), S. Herleth-King, J. Lane, and J. Westhoff. We thank K. Buhl, L. Cleveland, and two anonymous reviewers, for providing insightful comments that greatly improved the quality of this manuscript.

\section{Disclaimer}

Crayfish were collected in accordance with Missouri Department of Conservation Wildlife Collectors Permit regulations. To ensure humane treatment of the test organisms during culture and experimentation, this research was conducted according to the CERC Animal Welfare plan, in compliance with requirements of the US Laboratory Animal Welfare Act and the Intergency Research Animal Committee. Use of trade names does not constitute USGS or US Government endorsement.

\section{Appendix A. Supplementary Materials}

Supplementary data associated with this article can be found in the online version at doi:10.1016/j.ecoenv.2008.08.005.

\section{References}

Alikhan, M.A., Bagatto, G., Zia, S., 1990. Crayfish as a "biological indicator" of aquatic contamination by heavy metals. Water Resour. 24, 1069-1076.

Allert, A.L., Fairchild, J.F., DiStefano, R.J., Schmitt, C.J., Besser, J.M., Brumbaugh, W.G. Poulton, B.C., 2008. Effects of lead-zinc mining on crayfish (Orconectes hylas) in the Black River watershed, Missouri, USA. Freshwater Crayfish 16, 99-113.

APHA (American Public Health Association), American Water Works Association, Water Environment Federation, 2005. Standard Methods for the Examination of Water and Wastewater, 21st ed. American Public Health Association, Alexandria, VA.

Besser, J.M., Brumbaugh, W.G., May, T.W., Schmitt, C.J., 2006. Biomonitoring of lead, zinc, and cadmium in streams draining lead-mining and non-mining areas, southeast Missouri, USA. Environ. Monit. Assess. 129, 227-241. 
Besser, J.M., Mebane, C.A., Mount, D.R., Ivey, C.D., Kunz, J.L., Greer, I.E., May, T.W., Ingersoll, C.G., 2007. Sensitivity of mottled scuplins (Cottus bairdi) and rainbow trout (Onchorhynchus mykiss) to acute and chronic toxicity of cadmium, copper, and zinc. Environ. Tox. Chem. 26, 1657-1665.

Besser, J.M., et al., 2008. Ecological impacts of lead mining on Ozark streams: toxicity of sediment and pore water. Ecotoxicol. Environ. Saf. 72, 516-526.

Brumbaugh, W.G., Schmitt, C.J., May, T.W., 2005. Concentrations of cadmium, lead, and zinc in fish from mining-influenced waters of Northeastern Oklahoma: sampling of blood, carcass, and liver for aquatic biomonitoring. Arch. Environ. Contam. Toxicol. 49, 76-88.

Brumbaugh, W.G., May, T.W., Besser, J.M., Allert, A.L., Schmitt, C.J., 2007. Assessment of elemental concentrations in streams of Missouri's New Lead Belt: 2002-2005. US Geological Survey Report 2007-5057.

DiStefano, R.J., 2005. Trophic interactions between Missouri Ozarks stream crayfish communities and sport fish predators: increased abundance and size structure of predators cause little change in crayfish community densities. Missouri Department of Conservation, Dingell-Johnson Project F-1-R-054, Study S-41, Job 4, Final Report. Columbia, MO.

DiStefano, R.J., Young, J., Noltie, D.B., 2002. A study of the life history of Orconectes hylas with comparisons to Orconcectes peruncus and Orconectes quadruncus in Ozark streams, Missouri, USA. Freshwater Crayfish 13, 439-456.

Duchrow, R.M., 1983. Effects of lead tailings on benthos and water quality in three Ozark streams. Trans. Miss. Acad. Sci. 17, 5-17.

Gale, N.L., Wixson, B.G., Hardie, M.G., Jennett, J.C., 1973. Aquatic organisms and heavy metals in Missouri's new lead belt. Water Resour. Bull. 9, 673-688.

Giesy, J.P., Bowling, J.W., Kania, H.J., 1980. Cadmium and zinc accumulation and elimination by freshwater crayfish. Arch. Environ. Contam. Toxicol. 9, 683-697.

Gray, N.F., 1998. Acid mine drainage composition and the implications for its impact on lotic systems. Water Resour. 32, 2122-2134.

Flinders, C.A., Magoulick, D.D., 2005. Distribution, habitat use and life history of stream-dwelling crayfish in the Spring River drainage of Arkansas and Missouri with a focus on the Mammoth Spring crayfish (Orconectes marchandi). Am. Mid. Nat. 154, 358-374.

Huryn, A.D., Wallace, J.B., 1987. Production and litter processing by crayfish in an Appalachian mountain stream. Freshwater Biol. 18, 277-286.

Jessey, D.R., 1981. An investigation of the nickel-cobalt occurrence in the southeast Missouri mining district: Rolla, MO. Ph.D. Dissertation, University of Missouri-Rolla.

Knowlton, M.F., Boyle, T.P., Jones, J.R., 1983. Uptake of lead from aquatic sediment by submersed macrophytes and crayfish. Arch. Environ. Contam. Toxicol. 12 535-541.

Kuck, P.H., 2004. Nickel. In Minerals Yearbook, Volume I, Metals and Minerals: US Geological Survey, accessed January 2007 at URL <http://minerals.usgs.gov/ minerals/pubs/myb.html $\rangle$.

Kunz, J.L., Besser, J.M., May, T.W., Ingersoll, C.W., 2005. Toxicity of a metal mixture to stream-dwelling sculpins and crayfish. Poster TP109. SETAC North American 26th Annual Meeting, Baltimore, MD.

Lindhjem, P.A., Bennet-Chambers, M.G., 2002. Bioaccumulation and acute toxicity of zinc in marron, Cherax tenuimanus (Smith) [Decapoda: Parastacidae]. Freshwater Crayfish 13, 424-430.

Lodge, D.M., Kershner, J.W., Aloi, J.E., 1995. Effects of an omnivorous crayfish (Oronectes rusticus) on a freshwater littoral food web. Ecology 75, 165-1281.

May, T.W., Wiedmeyer, R.H., Brumbaugh, W.G., Schmitt, C.J., 1997. The determination of metals in sediment pore waters and in $1 \mathrm{~N} \mathrm{HCl}$-extracted sediments by ICP-MS. Atom. Spectrosc. 18, 133-139.

Mayers, D.A., 2003. 2001 Mail Survey Results of Lower Current River Anglers. Missouri Department of Conservation, Jefferson City, MO.

Mirenda, R.J., 1986a. Acute toxicity and accumulation of zinc in the crayfish, Orconectes virilis (Hagen). Bull. Environ. Contam. Toxicol. 37, 387-394.

Mirenda, R.J., 1986b. Toxicity and accumulation of cadmium in the crayfish Orconectes virilis (Hagen). Arch. Environ. Contam. Toxicol. 15, 401-407.

Missouri Department of Natural Resources, Geological Survey and Resources Assessment Division, 2004. The mineral industry of Missouri. In: Minerals
Yearbook, Volume I: US Geological Survey, accessed January 2007, at URL $\langle$ http://minerals.usgs.gov/minerals/pubs/state/2004/mostmyb04.pdf $\rangle$.

Missouri Department of Health and Senior Services, 2005. 2005 Fish Advisory, accessed February 2008, at URL 〈http://www.dhss.mo.gov/NewsAndPublicNotices/ 05FishAdvisory.pdf $>$.

Nagpal, N.K., 2004. Water quality guidelines for cobalt (electronic resource). Technical Report, accessed March 2008, at URL 〈http://www.env.gov.bc.ca/ wat/wq/BCguidelines/cobalt/cobalt_tech.pdf $>$.

Naqvi, S.M., Howell, R.D., 1993. Toxicity of cadmium and lead to juvenile red swamp crayfish, Procambarus clarkia, and the effects on fecundity of adults. Bull. Environ. Contam. Toxicol. 51, 303-308.

Parkyn, S.M., Collier, K.J., Hicks, B.J., 2001. New Zealand stream crayfish: functional omnivores but trophic predators. Freshwater Biol. 46, 641-652.

Pflieger, W.L., 1996. The Crayfishes of Missouri. Missouri Department of Conservation, Jefferson City, MO.

Probst, W.E., Rabeni, C.F., Covington, W.G., Marteney, R.E., 1984. Resource use by stream-dwelling rock bass and smallmouth bass. Trans. Am. Fish. Soc. 113, 283-294.

Rabeni, C.F., Gossett, M., McClendon, D.D., 1995. Contribution of crayfish to benthic invertebrate production and trophic ecology of an Ozark stream. Freshwater Crayfish 10, 163-173.

Ryck, F.M., Whitley, J.R., 1974. Pollution abatement in the lead mining district of Missouri. In: Proceedings of Purdue Industrial Waste Conference, vol. 29, pp. 857-863.

Schmitt, C.J., Brumbaugh, W.G., Linder, G.L., Hinck, J.E., 2006. A screening-level assessment of lead, cadmium, and zinc in fish and crayfish from northeastern Oklahoma, USA. Environ. Geochem. Health 38, 445-471.

Schmitt, C.J., Brumbaugh, W.G., May, T.W., 2007a. Accumulation of metals in fish from lead-zinc mining areas of southeastern Missouri, USA. Ecotoxicol. Environ. Saf. 67, 14-30.

Schmitt, C.J., Whyte, J.J., Roberts, A.P., Annis, M.L., Tillitt, D.E., 2007b. Biomarkers of metals exposure in fish from lead-zinc mining in southeastern Missouri, USA. Ecotoxicol. Environ. Saf. 67, 31-47.

Shedd, K.B., 2004. Cobalt. In: Minerals Yearbook, Volume I, Metals and Minerals: US Geological Survey, accessed January 2007 at URL <http://minerals.usgs. gov/minerals/pubs/myb.html $>$.

Thorp, J.H., Giesy, J.P., Wineriter, S.A., 1979. Effects of chronic cadmium exposure on crayfish survival, growth, and tolerance to elevated temperatures. Arch. Environ. Contam. Toxicol. 8, 449-456.

Tiwary, R.K., 2001. Environmental impacts of coal mining on water regime and its management. Water Air Soil Pollut. 132, 185-199.

USEPA, 2002. National Recommended Water Quality Criteria: 2002. Accessed January 2007, at 〈http://www.epa.gov/waterscience/criteria/aqlife.html >.

Usio, N., 2000. Effects of crayfish on leaf processing and invertebrate colonization of leaves in a headwater stream: decoupling of a trophic cascade. Oecologia $124,608-614$

Vijayram, K., Geraldine, P., 1996. Regulation of essential heavy metals ( $\mathrm{Cu}, \mathrm{Cr}$, and $\mathrm{Zn}$ ) by the freshwater prawn Macrobrachium malcolmsonii (Milne Edwards). Bull. Environ. Contamin. Toxicol. 56, 335-342.

Weithman, A.S., 1991. Recreational use and economic value of Missouri fisheries. Missouri Department of Conservation. Federal Aid in Sport Fish Restoration Project F-1-R-40, Study SI-1. Jefferson City, MO.

Whitledge, G.W., Rabeni, C.F., 1997. Energy sources and ecological role of crayfishes in an Ozark stream: insights from stable isotopes and gut analysis. Can. J. Fish. Aquat. Sci. 54, 2555-2563.

Wigginton, A.J., Birge, W.J., 2007. Toxicity of cadmium to six species in two genera of crayfish and the effect of cadmium on molting success. Environ. Toxicol. Chem. 26, 548-554.

Wixson, B.G., 1977. The Missouri lead study, vol. 1: an interdisciplinary investigation of environmental pollution by lead and other heavy metals from industrial development in the New Lead Belt of southeastern Missouri. Final report to the National Science Foundation. University of Missouri, Columbia and Rolla, MO. 